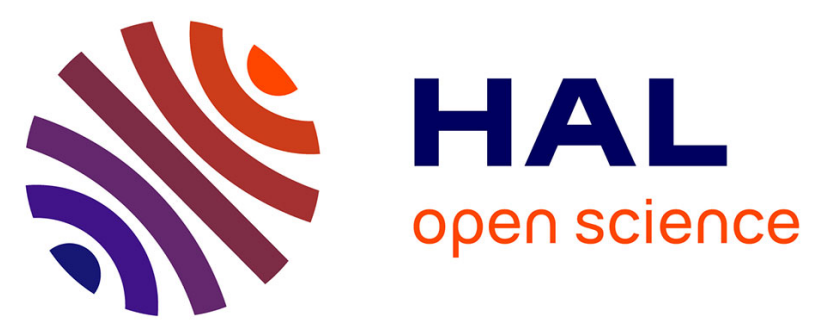

\title{
Unilateral or bilateral irradiation in cervical lymph node metastases of unknown primary? A retrospective cohort study
}

Carole Pflumio, Idriss Troussier, Xu Shan Sun, Julia Salleron, Claire Petit, Matthieu Caubet, Arnaud Beddok, Valentin Calugaru, Stéphanie Servagi-Vernat, Joël Castelli, et al.

\section{To cite this version:}

Carole Pflumio, Idriss Troussier, Xu Shan Sun, Julia Salleron, Claire Petit, et al.. Unilateral or bilateral irradiation in cervical lymph node metastases of unknown primary? A retrospective cohort study. European Journal of Cancer, 2019, 111, pp.69 - 81. 10.1016/j.ejca.2019.01.004 . hal-03486172

\section{HAL Id: hal-03486172 \\ https://hal.science/hal-03486172}

Submitted on 20 Dec 2021

HAL is a multi-disciplinary open access archive for the deposit and dissemination of scientific research documents, whether they are published or not. The documents may come from teaching and research institutions in France or abroad, or from public or private research centers.
L'archive ouverte pluridisciplinaire HAL, est destinée au dépôt et à la diffusion de documents scientifiques de niveau recherche, publiés ou non, émanant des établissements d'enseignement et de recherche français ou étrangers, des laboratoires publics ou privés.

\section{(ㅇ)(1) $\$$}

Distributed under a Creative Commons Attribution - NonCommerciall 4.0 International 
Title: Unilateral or bilateral irradiation in cervical lymph node metastases of unknown primary? A retrospective cohort study

Short title: CUP and radiotherapy

\section{Author names and affiliations:}

Carole Pflumio $^{\mathrm{a}}$, Idriss Troussier ${ }^{\mathrm{b}^{*}}, \mathrm{Xu}$ Shan Sun ${ }^{\mathrm{c}^{*}}$, Julia Salleron ${ }^{\mathrm{d}}$, Claire Petit ${ }^{\mathrm{e}}$, Matthieu Caubet $^{\mathrm{f}}$, Arnaud Beddok ${ }^{\mathrm{g}}$, Valentin Calugaru ${ }^{\mathrm{g}}$, Stéphanie Servagi-Vernat ${ }^{\mathrm{h}}$, Joël Castelli, Jessica Miroir ${ }^{\mathrm{j}}$, Marco Krengli ${ }^{\mathrm{k}}$, Paul Giraud ${ }^{1}$, Edouard Romano ${ }^{1}$, Jonathan Khalifa ${ }^{\mathrm{m}}$, Mélanie Doré $^{\mathrm{n}}$, Nicolas Blanchard ${ }^{\mathrm{o}}$, Alexandre Coutte ${ }^{\mathrm{p}}$, Charles Dupin ${ }^{\mathrm{q}}$, Shakeel Sumodhee ${ }^{\mathrm{q}}$, Yoann Pointreau, Samir Patel ${ }^{\mathrm{s}}$, Amel Rehailia-Blanchard,, Ludivine Catteau ${ }^{\mathrm{u}}$, René-Jean Bensadoun ${ }^{\mathrm{v}}$, Yungan Tao ${ }^{\mathrm{e}}$, Vincent Roth ${ }^{\mathrm{w}}$, Lionnel Geoffrois ${ }^{\mathrm{a}}$, Jean-Christophe Faivre ${ }^{\mathrm{x}}$, Juliette Thariat ${ }^{\mathrm{y}}$

${ }^{a}$ Department of Medical Oncology, Institut de Cancérologie de Lorraine, Vandoeuvre-lèsNancy, France

${ }^{\mathrm{b}}$ Department of Radiation Therapy, CHU Pitié Salpêtrière - Assistance Publique - Hôpitaux de Paris, Paris, France

${ }^{\mathrm{c}}$ Department of Radiation Therapy, Hôpital de Montbéliard, Montbéliard, France

${ }^{\mathrm{d}}$ Department of Biostatistics and Data Management, Institut de Cancérologie de Lorraine, Vandoeuvre-Lès-Nancy, France

${ }^{\mathrm{e}}$ Department of Radiation Therapy, Institut Gustave Roussy, Villejuif, France

${ }^{\mathrm{f}}$ Department of Radiation Therapy, CHU de Besançon, Besançon, France

${ }^{\mathrm{g}}$ Department of Radiation Therapy, Institut Curie, Paris, France

${ }^{\mathrm{h}}$ Department of Radiation Therapy, Institut Jean Godinot, Reims, France

${ }^{i}$ Department of Radiation Therapy, Institut Eugène Marquis, Rennes, France

${ }^{\mathrm{j}}$ Department of Radiation Therapy, Institut Jean Perrin, Clermont-Ferrand, France

${ }^{\mathrm{k}}$ Department of Radiation Therapy, University of Piemonte Orientale, Pavia, Italy

${ }^{1}$ Department of Radiation Therapy, Hôpital Tenon - Assistance Publique - Hôpitaux de Paris, Paris, France

${ }^{\mathrm{m}}$ Department of Radiation Therapy, Institut Universitaire du Cancer, Toulouse, France

${ }^{\mathrm{n}}$ Department of Radiation Therapy, Institut de Cancérologie de l'Ouest, Nantes, France

${ }^{\circ}$ Department of Radiation Therapy, Clinique les Dentellières, Valenciennes, France

${ }^{\mathrm{p}}$ Department of Radiation Therapy, CHU d'Amiens, Amiens, France

${ }^{\mathrm{q}}$ Department of Radiation Therapy, Centre Antoine Lacassagne, Nice, France

${ }^{\mathrm{r}}$ Department of Radiation Therapy, Clinique Victor Hugo, Le Mans, France 
${ }^{\mathrm{s}}$ Department of Radiation Therapy, Mayo Clinic, Arizona, USA

${ }^{\mathrm{t}}$ Department of Radiation Therapy, CHU de Saint-Étienne, Saint-Étienne, France

u Department of Radiation Therapy, CHU de Poitiers, Poitiers, France

${ }^{v}$ Department of Radiation Therapy, Centre de Haute Énergie, Nice, France

${ }^{\mathrm{w}}$ Easy CRF. 8 rue Lecourtois. Mathieu, France

$\mathrm{x}$ Academic Department of Radiation Therapy, Lorraine Institute of Cancerology, Vandoeuvre-lès-Nancy, France

${ }^{\mathrm{y}}$ Department of Radiation Therapy, Centre Francois Baclesse - Advanced Resource Center for Hadrontherapy in Europe, Caen, France- Unicaen-Normandie Universite

*equally contributed to the manuscript

Financing: CHU de Besançon - CH de Belfort-Montbéliard - Institut de Cancérologie de Lorraine

\section{Corresponding author:}

Prof Juliette Thariat. Department of Radiation Oncology, Centre François Baclesse, 3 Av General Harris, 14000 Caen, France

Tel: $+33251455050(5594)$

Email: jthariat@gmail.com 


\section{Abstract}

Introduction: Patients with cervical lymphadenopathy of unknown primary carcinoma (CUP) usually undergo neck dissection and irradiation. There is an ongoing controversy regarding the extent of nodal and mucosal volumes to be irradiated. We assessed outcomes after bilateral or unilateral nodal irradiation. Methods: This retrospective multicentre study included patients with CUP and squamous cellular carcinoma who underwent radiotherapy between 2000 and 2015. Results: Of 350 patients, $74.5 \%$ had unilateral disease and $25.5 \%$ had bilateral disease. Of 297 patients with available data on disease and irradiation sides, sixty-one (20.5\%) patients had unilateral disease and unilateral irradiation, 155 (52.2\%) unilateral disease and bilateral irradiation and 81 (27.3\%) bilateral disease and bilateral irradiation. Thirty-four (9.7\%) and $217(62.0 \%)$ patients received neoadjuvant and/or concomitant chemotherapy, respectively. Median follow-up was 37 months. Three-year local, regional, locoregional failure rates and CUP-specific survival were 5.6\%, 11.7\%, $15.0 \%$ and $84.7 \%$, respectively. In patients with unilateral disease, the three-year cumulative incidence of regional/local relapse was $7.7 \% / 4.3 \%$ after bilateral irradiation versus $16.9 \% / 11.1 \%$ after unilateral irradiation $(\mathrm{HR}=0.56 / 0.61, \mathrm{p}=0.17 / 0.32)$. The cumulative incidence of CUP-specific deaths was $9.2 \%$ after bilateral irradiation and $15.5 \%$ after unilateral irradiation $(p=0.92)$. In multivariate analysis, mucosal irradiation was associated with better local control, while no neck dissection, $\geq \mathrm{N} 2 \mathrm{~b}$ and interruption of radiotherapy for more than four days were associated with poorer regional control. Toxicity was higher after bilateral irradiation $(\mathrm{p}<0.05)$. No PET-CT, largest node diameter, $\geq \mathrm{N} 2 \mathrm{~b}$, neoadjuvant chemotherapy and interruption of radiotherapy were associated with poorer cause-specific survival. Conclusion: Bilateral nodal irradiation yielded non-significant better nodal and mucosal control rates but was associated with higher rates of severe toxicity. 
Keywords: neoplasms, unknown primary - head and neck neoplasms, radiotherapy, neck dissection, chemotherapy 


\section{Introduction}

Head and neck cancer of unknown primary (CUP) represents $1-4 \%$ of head and neck tumours $[1,2]$. Their diagnostic work-up includes fine-needle aspiration of the node(s), PET-CT and panendoscopy usually with tonsillectomy and/or mucosectomy [3-11], as well as human papilloma virus (HPV) and Epstein Barr Virus (EBV) testing since the 2017 TNM classification [12]. Neck dissection is used both as a diagnostic and therapeutic modality. Irradiation aims to prevent regional relapse $(\approx 10 \%$ of patients $)[8,13,14]$ and metachronous mucosal failure of the upper aerodigestive tract $(\approx 5-15 \%)[5,9,15]$. A current area of controversy is whether selective or extensive irradiation of nodal areas should be performed, and whether de-escalation of mucosal irradiation can be performed based on the low relapse rates, toxicity of extensive irradiation and presumed rates of HPV-related carcinomas. On the other hand, intensity-modulated radiation therapy (IMRT) has improved the tolerance to extensive nodal and mucosal irradiation to the point where it may prevent more locoregional relapses than elective irradiation while minimizing toxicity $[2,16,17]$. Due to the rarity of CUP, however, the level of evidence is currently based only on retrospective studies of less than 200 patients $[1,18-24]$. To date, no prospective randomized trial has ever been completed to advocate for or against either strategy, as the sole randomized trial (NCT00047125; unpublished) started was terminated early due to insufficient accrual.

We aimed to assess whether bilateral and unilateral nodal neck irradiation resulted in different outcomes in terms of local and regional control and of toxicities. 


\section{Material and methods}

This institutional review board- and ethical committee-approved retrospective, multicentre and international study included patients irradiated for CUP between 2000 and 2015. Patients with squamous cell CUP were included after proper diagnostic work-up showing absence of distant metastases and a histology-proven diagnosis of carcinoma, and were treated with curative external beam radiotherapy. The diagnostic work up has changed over time. For example, the use of PET-CT has become more systematic after 2008 after demonstration of its performances in the detection of mucosal head and neck primaries [25]. Apart from PETCT, the diagnostic work up of CUPs included FNA then panendoscopy and head neck and chest CT. Patients with adenocarcinomas (or non-squamous cell carcinomas), lymphomas, melanomas or sarcomas, or previous head and neck irradiation were excluded. Data were collected on https://www.easy-crf.com/ambicup/ (encrypted secured website) and included age, gender, imaging, nodal stage, extranodal spread, nodal diameter, histology, differentiation and HPV/EBV status. Treatment-related data included neck dissection, radiotherapy technique (three-dimensional (3D) or IMRT), total dose and fractions, interruption of radiotherapy, and target volumes: uni or bilateral nodal irradiation and their risk-dependent dose levels, pan-mucosal or elective or no mucosal irradiation, chemotherapy (neoadjuvant or concomitant).

We refer to microscopic mucosal disease turning into a macroscopic primary tumor if left untreated at the time of diagnosis of CUP. Of note, a second primary is usually defined as a primary tumor occurring in another site compared to first primary event. However, by definition CUP do not exhibit a primary. Another aspect of the definition for second primaries is time to occurrence later than 5 years after first event. 
Patients underwent follow-up visits according to standards at their institutions and their physician's discretion. Acute and late toxicities were based on the National Cancer Institute Common Terminology Criteria for Adverse Events, Version 3.0 (from descriptions in charts).

\section{Statistics}

Quantitative parameters were described by median, mean and standard deviation, qualitative parameters by frequency and percentage. Missing data were not computed in the percentages. Regional failure was defined as the persistence or recurrence of tumoral lymph node(s) and local failure as emergence of primary in the mucosae of the upper aerodigestive tract. Local, regional and locoregional relapses were described with the Fine and Gray model, to take into account competing risks such as emergence of metastases or death whatever the cause. For CUP-specific survival, we only considered death due to head and neck cancer, and the Fine and Gray model was also computed to consider death due to other causes as a competing risk. The Kaplan-Meier method was performed to describe overall survival (OS) defined as the time lapse between the date of diagnosis and the date of death, whatever the cause. The prognostic value of each factor was studied using the bivariate Gray model, and the results were expressed with the hazard ratio (HR) and its $95 \%$ confidence intervals. The parameters with a p-value less than 0.1 in bivariate analysis were introduced in a multivariate Gray model, with backward selection. All statistical analyses were performed using SAS software (SAS Institute Inc., Cary, NC 25513). P-values <0.05 were considered statistically significant. 


\section{Results}

From 2000 to 2015, 377 patients were irradiated for CUP, of whom 27 were excluded due to other histology $(n=2)$, no radiotherapy $(n=1)$ or insufficient follow-up data $(n=20)$. Patient and tumour characteristics of the 350 patients treated in 20 institutions are presented in Table 1. Patients with $\mathrm{N} 2 \mathrm{a} / \mathrm{b}$ disease represented the majority of the population, but N3 disease was also frequently observed. A majority $(74.5 \%)$ of patients had unilateral nodal disease, while $82(25.5 \%)$ patients had N2c or bilateral N3 disease. Fifty-eight (70.7\%) patients with bilateral disease had N3 presentation. Conventional squamous cell carcinomas accounted for 97.7\% of all carcinomas. Human papilloma status was tested in only 58 patients and was positive in 18 of them. Before 2005, 15\% of patients had a PET (or PET CT), in 2005 50\% and after 2006, 95\%.

Treatment characteristics are presented in Table 2. A majority of patients underwent neck dissection $(74.4 \%)$, while the other patients were either inoperable or had unresectable disease. All had nodal irradiation and 304 (87.6\%) had mucosal (elective or extended) irradiation. A majority of patients underwent concomitant chemotherapy (64.8\%) and 9.8\% had neoadjuvant chemotherapy. Among 297 patients with available data on disease and irradiation side, sixty-one (20.5\%) patients had unilateral disease and underwent unilateral irradiation, 155 (52.2\%) had unilateral disease and underwent bilateral irradiation and eightyone $(27.3 \%)$ patients had bilateral disease and bilateral irradiation. In 306 patients for whom target volume side was reported, there was $1 \%$ unilateral irradiation until 2008 (1/89). In contrast, after $2009,29 \%$ of the patients underwent bilateral irradiation $(63 / 216), \mathrm{p}<0.001$. Equal proportions of patients received 3D irradiation or IMRT. The oropharynx was the most commonly irradiated primary site $(84.9 \%)$, while the nasopharynx, larynx and hypopharynx were irradiated in two-thirds of the patients and the oral cavity in less than a quarter of patients. Those N1 patients who underwent RT were included, there were 39 (11.5\%) patients 
with N1 disease presented in Table 1. One patient underwent radiochemotherapy exclusively, others underwent neck dissection then radiochemotherapy.

The median follow-up was 37 months (IQR: 24; 63). Out of 256 patients living at last followup, $64(25.0 \%)$ patients had less than 24 months follow-up but at least three months followup. Crude failure rates are presented in Table 3. Ninety-three (26.6\%) patients had an isolated or combined relapse at a median time of 12 months. Of these, there were $26(7.4 \%)$ local relapses, $41(11.7 \%)$ regional relapses and $46(13.1 \%)$ metastatic relapses. Details of the patterns of failure are presented in Figure 1 (supplementary data). Among the five patients with bilateral nodal disease at diagnosis, four had bilateral relapse and one had unilateral relapse in the neck. Among the 36 patients with unilateral disease at diagnosis, 23 had unilateral relapse, seven had contralateral relapse and six patients had bilateral relapse. Of those patients with unilateral relapse, 19 had extended nodal irradiation (three patients without detailed nodal volume irradiation), with a median of five and a minimum of four nodal levels irradiated, suggesting that nodal relapse occurred in field. The median dose at the site of relapse was 54Gy (IQR 30; 60). Sixty-two (17.7\%) patients died of head and neck cancer. At last follow-up, $64.3 \%$ (225) patients were alive without disease. Cumulative threeyear incidence of local (Figure 2a), regional (Figure 2b) and locoregional (Figure 2c) failures were $5.6 \%$ [95\%CI $3.1-8.1], 11.8 \%$ [95\%CI $8.2-15.2]$ and $15.0 \%$ [95\%CI $1.0-18.8$, respectively. Three-year OS was $80.6 \%$ [95\%CI 75.5-84.8] and cumulative incidence of CUP-specific death was $15.3 \%$ [95\% CI 11.0-19.3]. Details of nodal and mucosal relapses are presented in supplementary data.

Prognostic factors of local, regional relapse and CUP-specific death are presented in Table 4. In multivariate analysis, mucosal irradiation was the only independent prognostic factor associated with better local control. There was no statistical difference between pan-mucosal and selective mucosal irradiation (HR 1.36 [0.48;3.86], $\mathrm{p}=0.55)$ among the 304 patients 
undergoing mucosal irradiation. There was no significant association between irradiation of mucosal site (oral cavity, oropharynx, nasopharynx, larynx or hypopharynx) and mucosal relapse (Table 4). In multivariate analysis, advanced (N2b/c and N3) or early (N1 and N2a) disease, no neck dissection and interruption of radiotherapy for more than four days were prognostic factors of regional relapse.

In multivariate analysis, absence of PET-CT at diagnosis, largest nodal diameter, N2c/N3 disease, neoadjuvant chemotherapy and interruption of radiotherapy were prognostic factors of CUP-specific death. Metastatic relapse was less frequent in patients with a PET-CT at diagnosis or than in those without (data not shown). There were no toxic deaths, therefore toxicity does not explain the more frequent CUP-specific deaths associated with neoadjuvant chemotherapy (data not shown).

Unilateral or bilateral nodal irradiation resulted in statistically similar outcomes (Table 4) for 297 patients with available data on disease and irradiation side (Figure 4). However, in patients with unilateral disease, the cumulative three-year incidence of local relapse (Figure 3a) was $4.3 \%$ [95\% CI 0.9-7.6] for those undergoing bilateral irradiation, while it was $11.1 \%$ [95\%CI 2.3-19.2] in patients undergoing unilateral irradiation $(\mathrm{p}=0.32$, HR 0.61 [95 CI 0.231.63]). Similarly, the cumulative incidence of regional failure (Figure 3b) was $7.7 \%$ [95\%CI 3.2-11.9] for those undergoing bilateral irradiation, while it was $16.9 \%$ [95\%CI 6.1-26.4] in patients undergoing unilateral irradiation ( $\mathrm{p}=0.17$, HR 0.56 [95 CI 0.25-1.27]). Locoregional incidence is shown in Figure 3c. Again, the cumulative incidence of CUP-specific deaths (Figure 3d) was 9.2\% [95\%CI 4.1-14.0] for those patients undergoing bilateral irradiation, while it was $15.5 \%$ [95\%CI 4.1-25.6] in patients undergoing unilateral irradiation $(\mathrm{p}=0.92$, HR 1.04[95\% CI 0.45-2.41]). The third group of patients, i.e. those patients with bilateral 
disease at diagnosis who underwent bilateral irradiation, had a cumulative incidence of CUPspecific deaths of $26.9 \%$ [95\%CI 15.1-37.0] ( $\mathrm{p}=0.06 \mathrm{HR}=2.28[95 \%$ CI $0.95-5.44])$.

There was no significant difference between $<=2008$ versus $>2008$ in terms of local relapse, regional relapse or CUP-related death (data not shown).

\section{Acute and late toxicities}

Severe (grade 3-4) acute and late toxicities are presented in Table 5. They were assessed in $301(86.0 \%)$ patients. There were no grade 5 (lethal) toxicities. Acute toxicities mostly consisted of dysphagia, mucositis and pain. Severe dysphagia and pain were more frequent in cases of bilateral nodal irradiation (both $\mathrm{p}<0.01$ ). Late toxicities, which occurred in less than $15 \%$ of all patients, mainly consisted of severe xerostomia, dysphagia and fibrosis. Severe xerostomia and dysphagia were more frequent after bilateral nodal irradiation (both $\mathrm{p}<0.01$ ). Toxicities were responsible for treatment interruption of four consecutive days or more in 23 $(6.6 \%)$ patients.

Bilateral irradiation was performed with $3 \mathrm{D}$ in $52 \%$ of patients $(127 / 242)$, while unilateral irradiation was performed with $3 \mathrm{D}$ in $16 \%$ of cases $(10 / 64, \mathrm{p}<0.001)$ only. There was a trend for more toxicities with bilateral 3D irradiation vs IMRT in case in bilateral disease. Patients undergoing bilateral irradiation $(n=242)$ with 3D irradiation vs IMRT had similar rates of severe acute toxicities but more late fibrosis $(12.1 \%$ (15) vs $0.9 \%$ (1); $\mathrm{p}<0.01)$, xerostomia $(25.8 \%$ (32) vs $6.3 \%$ (7); $p<0.01)$ and dysphagia (15.3\% (19) vs $2.7 \%(3) ; p<0.01)$. 


\section{Discussion}

With 350 patients, the present study is the largest to date in a rare subgroup of head and neck cancers, and it specifically addressed "standard" bilateral extended nodal volume irradiation versus de-escalation with unilateral (often elective) nodal irradiation in patients with CUP. Most patients underwent bilateral irradiation; $52.2 \%$ of them had bilateral irradiation for unilateral nodal disease, while $20.5 \%$ of them had unilateral irradiation for unilateral disease. Of note, IMRT became a standard of care in head and neck cancers in 2011 [2]. While some institutions have been advocating unilateral irradiation since around 1995 because of concerns around rare locoregional events and radiation toxicities, others have moved toward IMRTbased bilateral irradiation to decrease the rate of toxicities while maintaining excellent locoregional control rates. As a result, half the patients of this series were treated with IMRT. Our results suggest that some late toxicities after bilateral 3D irradiation can be avoided with IMRT. Thus, toxicities following bilateral or unilateral irradiation should be investigated in larger IMRT studies.

The present study shows that the regional control rate and occurrence of mucosal primaries did not differ between patients who had unilateral irradiation and those who had bilateral irradiation. However, as observed on curves of cumulative events in patients with unilateral disease at diagnosis, patients with bilateral irradiation appeared to do better compared to patients undergoing unilateral irradiation. Consistent with other series, the number of events was low, as $11.7 \%$ of patients had a regional relapse, and $7.4 \%$ had a mucosal failure during follow-up but the median follow-up was limited to 37 months (IQR: 24; 63). For Ligey et al, the nodal relapse rate was $34 \%$ after unilateral neck irradiation and $25 \%$ after bilateral radiotherapy $(\mathrm{p}=0.21)$ after a median follow-up of 3.3 years. A primary head and neck tumour occurred in $12 \%$ after unilateral irradiation and $6 \%$ after bilateral radiotherapy (difference not significant) [22-24]. The original hypothesis was that unilateral irradiation 
would be responsible for $15 \%$ more relapses than bilateral irradiation. However, a quarter of patients had bilateral disease at diagnosis and half the patients underwent 3D irradiation. Thus, we will investigate whether the benefit of bilateral irradiation in patients with unilateral disease might become significant (with a power of 80\%) in a larger study which includes 591 additional patients, with 272 patients undergoing unilateral IMRT. We will also assess the ongoing trend to de-escalate nodal and mucosal radiotherapy volume, and ultimate disease control after salvage treatment of nodal and/or mucosal failures. On the other hand, this present study shows that both selective and pan-mucosal irradiation, the latter extending from the nasopharynx to the hypopharynx and larynx, helped to avoid mucosal failures and allowed a significant CUP-specific survival benefit compared to no mucosal irradiation. Further data are needed to investigate whether elective mucosal irradiation yields similar local control to, and fewer late severe toxicities than, pan-mucosal irradiation. Altogether, our observations favour bilateral nodal irradiation and mucosal irradiation.

As for nodal control, advanced stage and no neck dissection were associated with poorer regional control. As most patients were French, they underwent upfront neck dissection per national CUP policy. Thus, patients undergoing non-surgical options upfront and no neck dissection afterwards [26] were an unfavourable group, and neoadjuvant chemotherapy did not compensate for their poorer prognosis. Moreover, neck dissection improves locoregional control but not survival in the era of chemoradiation for CUP. For example, in a meta-analysis by Balaker et al, patients who underwent neck dissection with either postoperative radiation or chemoradiation had a 5-year survival of $52.4 \%$ compared to $46.6 \%$ for those treated with chemoradiation alone; however, this difference was not statistically significant [27-29]. Omission of neck dissection, which is responsible for shoulder, neural (XI) and swallowing morbidity, was not our study aim and was not evaluated in our series due to neck dissection policy. 
Interestingly, in addition to advanced nodal stage and size [28, 29], neoadjuvant chemotherapy and interruption of radiotherapy, the fact that absence of PET-CT at diagnosis had a negative effect on CUP-specific survival is intriguing. It is possible that patients not undergoing PET-CT at diagnosis were more likely to have subclinical metastases, and so died of symptomatic metastases later in follow-up, than those with no metastases on PET-CT [25]. Another hypothesis is that PET-CT improves the definition of nodal target volumes before neck dissection and irradiation [30]. In contrast to neoadjuvant chemotherapy, concomitant chemotherapy was not associated with poorer prognosis. Most patients received cisplatin where poor prognostic factors, as defined in other head and neck cancers [31, 32], were identified following evaluation of the neck dissection specimen.

Study limitations include the lack of systematic HPV testing. However, to date, HPV testing is only recommended in oropharyngeal cancers and EBV for nasopharyngeal cancers only. Reporting of HPV or EBV status has not been standard practice in participating institutions. In this series, all patients had unknown primaries (T0) after thorough diagnostic locoregional and distant procedures. While recent retrospective studies suggest that HPV testing should be systematic [34] to advocate treatment de-escalation $[33,35,36]$, such data may be premature if the unknown (yet microscopic) primary indeed resides in the larynx or hypopharynx. In our series, only five out the 26 mucosal relapses occurred in the oropharynx only. Whether HPVguided de-escalation of radiotherapy volumes is relevant regardless of the involved neck level(s) is questionable given the results of our study. Such a strategy might better apply to cystic nodes and/or levels 2 and 3 , and should be investigated with more stringent methodology. The TNM 2017 classification might be overemphasizing the value of HPV testing. As suggested by the landmark Lindberg study in 1972, the risk for nodal involvement can be estimated based on the primary location. The reverse may be applied for CUPs. 
There could be an effect of time and that was indeed our initial hypothesis but there was however no significant difference between $<=2008$ versus $>2008$ in terms of local relapse, regional relapse or CUP-related death in our study. We had observed a progressive switch in practice despite $1 /$ no or very limited level of evidence in favour of unilateral irradiation rather than bilateral irradiation 2/ no major event in favour of unilateral irradiation $3 /$ the possibility to limit the morbidity of irradiation (and in particular bilateral irradiation) with IMRT. To investigate the latter hypothesis, the length of the study rather appears as a strength as we could collect data from patients with similar disease presentation but undergoing either 3D or IMRT.

Trends in PET CT have clearly changed dramatically over years. We analyzed rates more specifically. Before 2005, 15\% of patients had a PET (or PET CT), in $200550 \%$ and after 2006, 95\%. There was however no impact of PET CT on locoregional control. It was related to CUP-specific death. Our hypothesis is that metastatic patients were excluded while some may have been included in the study if they had had no PET CT due to undiagnosed metastases.

Missing data are clearly a weakness as in many retrospective studies, but it is indicated and even with incomplete patient data for certain items, this remains a large study compared to other CUP publications (297 patients with available data on disease and irradiation sides out of 350 patients $=84 \%$ ). Of note, the 53 patients with missing data on disease and irradiation sides had comparable characteristics than the others (data not show). Consequently, the 297 patients are representative for the whole population. Unfortunately, the location of the initial nodal desease is missing but N-stage and unilateral/bilateral desease are clearly specified. By being multicentric, we may consider that this study allowed for investigating the impact of dose and technique, in contrast to a monocentric with single practice. 
16000 new head and neck cases are diagnosed in France; ie about 600 cases with CUPs. It is difficult to get exhaustivity in retrospective studies but we tried to have a representation of differents kinds of health care institutions (private, public, tertiary versus regional centers etc). Thus the number achieved is representative and relevant to investigate radiation practice thus it is a full overview.

\section{Conclusion}

This large study of cervical lymphadenopathies of unknown primary suggests that unilateral neck irradiation may not yet be the treatment standard, as it may result in slightly worse rates of mucosal and nodal relapse. Severe toxicities were, however, more frequent after bilateral irradiation than unilateral irradiation. Molecular biomarkers are probably necessary to better predict the primary site of origin in a way that is adapted for the neck levels involved. However, not all CUPs are HPV-positive. Thus, de-escalation of the volumes of nodal and/or mucosal irradiation with IMRT should be investigated further. The prognostic impact of the $8^{\text {th }}$ TNM 2017 classification, which takes into account EBV and HPV in CUP, should also be assessed. We are continuing this study so as to collect enough patients to reach sufficient power.

Acknowledgements: The manuscript has been revised for the English by an independent scientific language editing service (Angloscribe).

Conflict of interest statement: The authors have declared no conflicts of interest with respect to the study 


\section{References}

1. Galloway, T.J. and J.A. Ridge, Management of Squamous Cancer Metastatic to Cervical Nodes With an Unknown Primary Site. J Clin Oncol, 2015. 33(29): p. 3328-37.

2. Grau, C., et al., Cervical lymph node metastases from unknown primary tumours. Results from a national survey by the Danish Society for Head and Neck Oncology. Radiother Oncol, 2000. 55(2): p. 121-9.

3. Kwee, T.C., S. Basu, and A. Alavi, PET and PET/CT for unknown primary tumors. Methods Mol Biol, 2011. 727: p. 317-33.

4. Rusthoven, K.E., M. Koshy, and A.C. Paulino, The role of fluorodeoxyglucose positron emission tomography in cervical lymph node metastases from an unknown primary tumor. Cancer, 2004. 101(11): p. 2641-9.

5. Troussier, I., et al., [Advances in the management of cervical lymphadenopathies of unknown primary; advances in diagnostic imaging and surgical modalities and new international staging system]. Bull Cancer, 2017.

6. Waltonen, J.D., et al., Metastatic carcinoma of the neck of unknown primary origin: evolution and efficacy of the modern workup. Arch Otolaryngol Head Neck Surg, 2009. 135(10): p. 1024-9.

7. Chen, Y.H., et al., Value of fused positron emission tomography CT in detecting primaries in patients with primary unknown cervical lymph node metastasis. J Med Imaging Radiat Oncol, 2012. 56(1): p. 66-74.

8. de Ridder, M., et al., Unknown primary head and neck squamous cell carcinoma in the era of fluorodeoxyglucose-positron emission tomography/CT and intensity-modulated radiotherapy. Head Neck, 2017. 39(7): p. 1382-1391.

9. Arosio, A.D., et al., Neck lymph node metastases from unknown primary. Cancer Treat Rev, 2017. 53: p. 1-9.

10. Mani, N., et al., Role of 18-Fludeoxyglucose positron emission tomography-computed tomography and subsequent panendoscopy in head and neck squamous cell carcinoma of unknown primary. Laryngoscope, 2016. 126(6): p. 1354-8.

11. Smith, A.F., et al., Cost-effectiveness analysis of PET-CT-guided management for locally advanced head and neck cancer. Eur J Cancer, 2017. 85: p. 6-14.

12. Motz, K., et al., Changes in Unknown Primary Squamous Cell Carcinoma of the Head and Neck at Initial Presentation in the Era of Human Papillomavirus. JAMA Otolaryngol Head Neck Surg, 2016. 142(3): p. 223-8.

13. Hamoir, M., et al., The role of neck dissection in the setting of chemoradiation therapy for head and neck squamous cell carcinoma with advanced neck disease. Oral Oncol, 2012. 48(3): p. 203-10.

14. Thariat, J., et al., Prediction of neck dissection requirement after definitive radiotherapy for head-and-neck squamous cell carcinoma. Int J Radiat Oncol Biol Phys, 2012. 82(3): p. e36774.

15. Chen, A.M., et al., Improved dosimetric and clinical outcomes with intensity-modulated radiotherapy for head-and-neck cancer of unknown primary origin. Int J Radiat Oncol Biol Phys, 2011. 79(3): p. 756-62.

16. Madani, I., et al., Intensity-modulated radiotherapy for cervical lymph node metastases from unknown primary cancer. Int J Radiat Oncol Biol Phys, 2008. 71(4): p. 1158-66.

17. Nutting, C.M., et al., Parotid-sparing intensity modulated versus conventional radiotherapy in head and neck cancer (PARSPORT): a phase 3 multicentre randomised controlled trial. Lancet Oncol, 2011. 12(2): p. 127-36.

18. Glynne-Jones, R.G., et al., Metastatic carcinoma in the cervical lymph nodes from an occult primary: a conservative approach to the role of radiotherapy. Int J Radiat Oncol Biol Phys, 1990. 18(2): p. 289-94.

19. Marcial-Vega, V.A., et al., Cervical metastases from unknown primaries: radiotherapeutic management and appearance of subsequent primaries. Int J Radiat Oncol Biol Phys, 1990. 19(4): p. 919-28. 
20. Perkins, S.M., et al., Radiotherapeutic management of cervical lymph node metastases from an unknown primary site. Arch Otolaryngol Head Neck Surg, 2012. 138(7): p. 656-61.

21. Reddy, S.P. and J.E. Marks, Metastatic carcinoma in the cervical lymph nodes from an unknown primary site: results of bilateral neck plus mucosal irradiation vs. ipsilateral neck irradiation. Int J Radiat Oncol Biol Phys, 1997. 37(4): p. 797-802.

22. Weir, L., et al., Radiation treatment of cervical lymph node metastases from an unknown primary: an analysis of outcome by treatment volume and other prognostic factors. Radiother Oncol, 1995. 35(3): p. 206-11.

23. Colletier, P.J., et al., Postoperative radiation for squamous cell carcinoma metastatic to cervical lymph nodes from an unknown primary site: outcomes and patterns of failure. Head Neck, 1998. 20(8): p. 674-81.

24. Ligey, A., et al., Impact of target volumes and radiation technique on loco-regional control and survival for patients with unilateral cervical lymph node metastases from an unknown primary. Radiother Oncol, 2009. 93(3): p. 483-7.

25. Johansen, J., et al., Prospective study of 18FDG-PET in the detection and management of patients with lymph node metastases to the neck from an unknown primary tumor. Results from the DAHANCA-13 study. Head Neck, 2008. 30(4): p. 471-8.

26. Mehanna, H., et al., PET-CT Surveillance versus Neck Dissection in Advanced Head and Neck Cancer. N Engl J Med, 2016. 374(15): p. 1444-54.

27. Amsbaugh, M.J., et al., Neck dissection for unknown cancer of the head and neck in the era of chemoradiation. Am J Otolaryngol, 2017. 38(5): p. 588-592.

28. $\mathrm{Al}$ Kadah, B., et al., Cancer of unknown primary (CUP) of the head and neck: retrospective analysis of 81 patients. Eur Arch Otorhinolaryngol, 2017. 274(6): p. 2557-2566.

29. Balaker, A.E., et al., Cancer of unknown primary: does treatment modality make a difference? Laryngoscope, 2012. 122(6): p. 1279-82.

30. Lonneux, M., et al., Positron emission tomography with [18F]fluorodeoxyglucose improves staging and patient management in patients with head and neck squamous cell carcinoma: a multicenter prospective study. J Clin Oncol, 2010. 28(7): p. 1190-5.

31. Bernier, J., et al., Postoperative irradiation with or without concomitant chemotherapy for locally advanced head and neck cancer. N Engl J Med, 2004. 350(19): p. 1945-52.

32. Al-Sarraf, M., et al., Chemoradiotherapy versus radiotherapy in patients with advanced nasopharyngeal cancer: phase III randomized Intergroup study 0099. J Clin Oncol, 1998. 16(4): p. 1310-7.

33. Strojan, P., et al., Squamous cell carcinoma of unknown primary tumor metastatic to neck nodes: role of elective irradiation. Eur Arch Otorhinolaryngol, 2016. 273(12): p. 4561-4569.

34. Zhou, M.J., et al., Squamous cell carcinoma of unknown primary of the head and neck: Favorable prognostic factors comparable to those in oropharyngeal cancer. Head Neck, 2017.

35. Schroeder, L., et al., Human papillomavirus as prognostic marker with rising prevalence in neck squamous cell carcinoma of unknown primary: A retrospective multicentre study. Eur J Cancer, 2017. 74: p. 73-81.

36. Chen, A.M., et al., Oropharynx-directed ipsilateral irradiation for p16-positive squamous cell carcinoma involving the cervical lymph nodes of unknown primary origin. Head Neck, 2017. 


\section{Tables and Figures}

\section{Figures: no color necessary}

Figure 1 (supplementary data): patterns of failure

Figure $2 \mathrm{a}, \mathrm{b}$, and c: Cumulative incidence of local relapses, regional relapses and causespecific deaths for all patients

Figure 3 a, b, c and d: Cumulative incidence of local relapses, regional relapses, locoregional relapses and cause-specific deaths for the 297 patients with available data on disease and irradiation side

Figure 4: Distribution of the site of treatment failure

\section{Tables}

Table 1: Patient and tumour characteristics

Footnotes: Results presented with frequency and percentage (n\%) or by median; mean \pm standard deviation. CT, Computerized tomography; HPV, Human papillomavirus; MRI, Magnetic resonance imaging; NOS, Not otherwise specified; SCC, Squamous cell carcinoma; 18FDG PET, 18Fluorodeoxyglucose positron emission tomography

$*$ Missing data $>10 \%$ : Differentiation $=53$, Extranodal spread $=37, \mathrm{HPV}=292$

Table 2: Characteristics of irradiation, surgery and other antineoplastic treatments

Footnotes: Results presented with frequency and percentage (n\%) or by median; mean \pm standard deviation

IMRT, Intensity-modulated radiation therapy; Gy, Gray; Uni-D Uni-I, unilateral disease at diagnosis undergoing unilateral irradiation; Uni-D Bi-I, unilateral disease at diagnosis 
undergoing bilateral irradiation; Bi-D Bi-I, Bilateral disease at diagnosis undergoing bilateral irradiation; NRT, Nodal radiotherapy; HR, High risk level; IR, Intermediate risk level; LR, Low risk level

$*$ Missing data >10\%: Group $=53$, RTN dose level $=42$, Radiotherapy target volume $=44$

Table 3: Description of crude rates of each outcome over all follow-up period and status on last follow-up.

Footnotes: Results presented with frequency and percentage $(\mathrm{n} \%)$ or by median; mean \pm standard deviation. Gy, Gray; RP, retropharyngeal lymph nodes

Table 4: Prognostic factors of local and regional relapse and cause-specific death in bivariate and multivariate analyses using the Gray model for competing risk data Footnotes: *Variables included in multivariate analysis with backward selection. HR 95\% CI, Hazard ratio 95\% confidence interval; 18 FDG PET, 18Fluorodeoxyglucose positron emission tomography; SCC, Squamous cell carcinoma; IMRT, Intensity-modulated radiation therapy; 3D, Three-dimensional; Uni-D Uni-I, unilateral disease at diagnosis undergoing unilateral irradiation; Uni-D Bi-I, unilateral disease at diagnosis undergoing bilateral irradiation; Bi-D Bi-I, Bilateral disease at diagnosis undergoing bilateral irradiation; Gy, Gray; RTN, Nodal radiotherapy; HR, High risk level; IR, Intermediate risk level; LR, Low risk level; RT, radiotherapy

Table 5: Acute and late adverse events grade 3-4. Footnotes: Nc, Not calculated; RTN, Nodal radiotherapy. Results expressed with frequency and percentages

Table 6 (supplementary data): Sides of mucosal and regional relapses 
Table 1: Patient and tumour characteristics

\begin{tabular}{|c|c|}
\hline Characteristics & \\
\hline Age (years) & $61.6 ; 62.4 \pm 10.2$ \\
\hline Male gender & $290(82.9 \%)$ \\
\hline \multicolumn{2}{|l|}{ Initial imaging } \\
\hline Aerodigestiv tract endoscopy under general anaesthesia & $329(96 \%)$ \\
\hline Head and neck CT & $330(94.6 \%)$ \\
\hline Head and neck MRI & $48(13.8 \%)$ \\
\hline Chest abdomen pelvis $\mathrm{CT}$ & $190(56.7 \%)$ \\
\hline 18FDG PET-CT & $285(82.1 \%)$ \\
\hline \multicolumn{2}{|l|}{ Histology } \\
\hline Conventional squamous cell carcinoma (SCC) & $342(97.7 \%)$ \\
\hline SCC variant & $8(2.3 \%)$ \\
\hline \multicolumn{2}{|l|}{ Differentiation* } \\
\hline Well differentiated & $125(42.1 \%)$ \\
\hline Keratinizing & $90(30.3 \%)$ \\
\hline Non-keratinizing & $24(8.1 \%)$ \\
\hline Not otherwise specified (NOS) & $11(3.7 \%)$ \\
\hline Moderately differentiated & $79(26.6 \%)$ \\
\hline Poorly differentiated & $82(27.6 \%)$ \\
\hline Undifferentiated & $11(3.7 \%)$ \\
\hline HPV positive* (58 tested) & $18(31.0 \%)$ \\
\hline \multicolumn{2}{|l|}{ Nodal stage } \\
\hline $\mathrm{N} 1$ & $39(11.5 \%)$ \\
\hline $\mathrm{N} 2 \mathrm{a}$ & $70(20.6 \%)$ \\
\hline $\mathrm{N} 2 \mathrm{~b}$ & $117(34.5 \%)$ \\
\hline $\mathrm{N} 2 \mathrm{c}$ & $24(7.1 \%)$ \\
\hline N3 & $89(26.3 \%)$ \\
\hline Unilateral nodal disease & $240(74.5 \%)$ \\
\hline Bilateral nodal disease & $82(25.5 \%)$ \\
\hline Extranodal spread* & $222(70.9 \%)$ \\
\hline Diameter of largest node $(\mathrm{cm})$ & $4.5 ; 5.6 \pm 6.0$ \\
\hline
\end{tabular}


Table 2: Characteristics of irradiation, surgery and other antineoplastic treatments

\begin{tabular}{|c|c|}
\hline Characteristics & \\
\hline \multicolumn{2}{|l|}{ Surgery } \\
\hline Tonsillectomy & $101(29 \%)$ \\
\hline Neck dissection & $259(74.4 \%)$ \\
\hline Radiotherapy & $350(100 \%)$ \\
\hline IMRT & $177(50.6 \%)$ \\
\hline Duration of radiotherapy (days) & $49.0 ; 48.6 \pm 10.9$ \\
\hline Nodal irradiation & $350(100 \%)$ \\
\hline Total dose (Gy) & $66.0 ; 64.0 \pm 6.9$ \\
\hline$\leq 56$ & $47(13.4 \%)$ \\
\hline$>56$ and $\leq 63$ & $34(9.7 \%)$ \\
\hline$>63$ & $269(76.9 \%)$ \\
\hline Number of fractions & $33.0 ; 32.0 \pm 4.7$ \\
\hline \multicolumn{2}{|l|}{ Group $(n=297 *)$} \\
\hline Unilateral disease \& unilateral irradiation & $61(20.5 \%)$ \\
\hline Unilateral disease \& bilateral irradiation & $155(52.2 \%)$ \\
\hline Bilateral disease \& bilateral irradiation & $81(27.3 \%)$ \\
\hline \multicolumn{2}{|l|}{ Radiotherapy target volume $\left(\mathrm{n}=306^{*}\right)$} \\
\hline High-risk nodal level & $254(81.9 \%)$ \\
\hline Dose (Gy) & $66.0 ; 65.8 \pm 5.1$ \\
\hline Ipsilateral / Bilateral / None & $226(73.9 \%) / 28(9.2 \%) / 52(17.0 \%)$ \\
\hline Intermediate risk nodal level & $136(43.7 \%)$ \\
\hline Dose (Gy) & $59.4 ; 58.8 \pm 4.5$ \\
\hline Ipsilateral / Contralateral / Bilateral / None & $\begin{array}{c}93(30.4 \%) / 5(1.6 \%) / 37(12.1 \%) / 171 \\
(55.9 \%)\end{array}$ \\
\hline Low risk nodal level & $275(89.0 \%)$ \\
\hline Dose (Gy) & $50.0 ; 51.8 \pm 3.0$ \\
\hline Ipsilateral / Contralateral / Bilateral / None & $\begin{array}{c}50(16.3 \%) / 39(12.8 \%) / 186(60.8 \%) / \\
31(10.1 \%)\end{array}$ \\
\hline Mucosal irradiation & $304(87.6 \%)$ \\
\hline Total dose (Gy) & $50.0 ; 53.6 \pm 5.9$ \\
\hline Number of fractions & $25.0 ; 28.1 \pm 4.6$ \\
\hline \multicolumn{2}{|l|}{ Target volume } \\
\hline Nasopharynx including unilateral / bilateral irradiation & $221(66.4 \%) / 39(17.9 \%) / 179(82.1 \%)$ \\
\hline Oropharynx including unilateral / bilateral irradiation & $292(84.9 \%) / 59(20.6 \%) / 227(79.4 \%)$ \\
\hline Hypopharynx including unilateral / bilateral irradiation & $258(75.4 \%) / 39(15.5 \%) / 213(84.5 \%)$ \\
\hline Larynx including unilateral / bilateral irradiation & $219(64.4 \%) / 20(9.4 \%) / 194(90.7 \%)$ \\
\hline Oral cavity including unilateral / bilateral irradiation & $77(23.8 \%) / 24(32.4 \%) / 50(67.6 \%)$ \\
\hline Chemotherapy & $226(64.8 \%)$ \\
\hline Neoadjuvant & $34(9.8 \%)$ \\
\hline Concomitant & $217(62.2 \%)$ \\
\hline
\end{tabular}

Results presented with frequency and percentage ( $\mathrm{n} \%$ ) or by median; mean \pm standard deviation

IMRT, Intensity-modulated radiation therapy; Gy, Gray; Uni-D Uni-I, unilateral disease at diagnosis undergoing unilateral irradiation; NRT,

Nodal radiotherapy

$*$ Missing data $>10 \%$ : Group $=53$, RTN dose level $=42$, Radiotherapy target volume $=44$. Totals account for missing data, percentages are

calculated with known data only 
Table 3: Description of crude rates of each outcome

\begin{tabular}{|c|c|}
\hline Any relapse & $93(26.6 \%)$ \\
\hline Mean delay of relapse (months) & $11.7 ; 20.3 \pm 22.6$ \\
\hline Local (mucosal) relapse of the head and neck & $26(7.4 \%)^{*}$ \\
\hline Several sites & 5 \\
\hline Hypopharynx & 6 \\
\hline Oropharynx & 5 \\
\hline Oral cavity & 5 \\
\hline Nasopharynx & 1 \\
\hline Larynx & 0 \\
\hline Unspecified & 4 \\
\hline Regional relapse (nodes) & $41(11.7 \%)$ \\
\hline Contralateral relapse & 7 \\
\hline Ipsilateral relapse (including 1 with bilateral disease) & 24 \\
\hline Bilateral relapse ( 4 bilateral disease and 6 unilateral disease) & 10 \\
\hline Metastatic relapse* & $46(13.1 \%)$ \\
\hline Lung & 27 \\
\hline Bone & 15 \\
\hline Liver & 6 \\
\hline Mediastinum & 7 \\
\hline Brain & 3 \\
\hline Skin & 3 \\
\hline Other & 4 \\
\hline Second cancer (non-head and neck) & 5 \\
\hline \multicolumn{2}{|l|}{ Status on last follow-up } \\
\hline Dead due to head and neck cancer & $62(17.7 \%)$ \\
\hline Dead due to other cancer & $17(4.9 \%)$ \\
\hline Dead due to other cause (not cancer) & $15(4.3 \%)$ \\
\hline Alive with active disease & $31(8.9 \%)$ \\
\hline Alive without disease & $225(64.2 \%)$ \\
\hline
\end{tabular}

Legend: Gy, Gray; RP, retropharyngeal lymph nodes

Results presented with frequency and percentage ( $\mathrm{n} \%)$ or by median; mean \pm standard deviation

*Totals are not necessarily equal to the sum of events because there may be several synchronous events

Totals account for missing data, percentages are calculated with known data only 
Table 4: Prognostic factors of local and regional relapse and cause-specific death in bivariate and multivariate analyses using the Gray model for competing risk data

\begin{tabular}{|c|c|c|c|c|c|c|c|c|c|c|c|c|}
\hline & \multicolumn{4}{|c|}{ Local relapse } & \multirow{2}{*}{\multicolumn{4}{|c|}{ Regional relapse }} & \multicolumn{4}{|c|}{ CUP Specific death } \\
\hline & \multicolumn{2}{|c|}{ Bivariate analyses } & \multicolumn{2}{|c|}{ Multivariate analysis } & Bivariate analyses & & & Multivariate analysis & \multicolumn{2}{|c|}{ Bivariate analyses } & \multicolumn{2}{|c|}{ Multivariate analysis } \\
\hline & HR 95\% CI & $\mathrm{p}$ & $\mathrm{HR} 95 \% \mathrm{CI}$ & $\mathrm{p}$ & $\mathrm{HR} 95 \% \mathrm{CI}$ & $\mathrm{p}$ & $\mathrm{HR} 95 \% \mathrm{CI}$ & $\mathrm{p}$ & $\mathrm{HR} 95 \% \mathrm{CI}$ & $\mathrm{p}$ & HR 95\% CI & $\mathrm{p}$ \\
\hline \multicolumn{13}{|l|}{ Patients and tumours } \\
\hline Male gender & $2.55[0.62 ; 10.60]$ & 0.20 & & & $1.52[0.60 ; 3.85]$ & 0.37 & & & $3.15[1.15 ; 8.67]$ & $0.03^{*}$ & & \\
\hline Age & $1.04[1.0 ; 1.09]$ & $0.07 *$ & & & $1.02[1.00 ; 1.05]$ & 0.11 & & & $1.00[0.97 ; 1.02]$ & 0.84 & & \\
\hline 18FDG PET & $0.63[0.28 ; 1.43]$ & 0.27 & & & $0.84[0.40 ; 1.79]$ & 0.66 & & & $0.41[0.24 ; 0.71]$ & $<0.01^{*}$ & $0.43[0.23 ; 0.80]$ & $<0.01$ \\
\hline Neck dissection & $0.87[0.36 ; 2.08]$ & 0.76 & & & $0.39[0.21 ; 0.73]$ & $<0.01^{*}$ & $0.43[0.23 ; 0.83]$ & 0.01 & $0.70[0.40 ; 1.23]$ & 0.22 & & \\
\hline Diameter of largest node $(\mathrm{cm})$ & $0.99[0.95 ; 1.03]$ & 0.65 & & & $1.02[0.99 ; 1.06]$ & 0.17 & & & $1.06[1.04 ; 1.08]$ & $<0.01^{*}$ & $1.06[1.03 ; 1.09]$ & $<0.01$ \\
\hline \multicolumn{13}{|l|}{ TNM } \\
\hline $\mathrm{N} 1+\mathrm{N} 2 \mathrm{a}$ & $\begin{array}{c}1 \\
069[024 \cdot 2001\end{array}$ & & & & $\begin{array}{c}1 \\
213[82.5531\end{array}$ & & $\begin{array}{c}1 \\
234[092.596\end{array}$ & & $\begin{array}{c}1 \\
154[074 \cdot 319]\end{array}$ & & & \\
\hline $\mathrm{N} 2 \mathrm{~b}$ & $0.69[0.24 ; 2.00]$ & 0.50 & & & $2.13[0.82 ; 5.53]$ & 0.12 & & 0.07 & $1.54[0.74 ; 3.19]$ & 0.25 & $1.07[0.46 ; 2.47]$ & 0.87 \\
\hline $\mathrm{N} 2 \mathrm{c}+\mathrm{N} 3$ & $1.24[0.49 ; 3.13]$ & 0.65 & & & $3.94[1.61 ; 9.66]$ & $<0.01 *$ & $3.49[1.43 ; 8.49]$ & $<0.01$ & $3.67[1.87 ; 7.21]$ & $<0.01 *$ & $2.68[1.32 ; 5.43]$ & $<0.01$ \\
\hline Extranodal spread & $1.03[0.41 ; 2.59]$ & 0.95 & & & $1.69[0.74 ; 3.87]$ & 0.21 & & & $2.24[1.06 ; 4.73]$ & $0.04 *$ & & \\
\hline SCC & $0.64[0.16 ; 2.68]$ & 0.55 & & & $0.71[0.23 ; 2.23]$ & 0.56 & & & $0.82[0.30 ; 2.25]$ & 0.70 & & \\
\hline \multicolumn{13}{|l|}{ Differentiation } \\
\hline $\begin{array}{l}\text { Well differentiated } \\
\text { Moderate+poor+undifferentiated }\end{array}$ & $\begin{array}{c}1 \\
1.76[0.65 ; 4.75]\end{array}$ & 0.27 & & & $\begin{array}{c}1 \\
0.53[0.28 ; 0.99]\end{array}$ & $0.047 *$ & & & $\begin{array}{c}1 \\
0.70[0.41: 1.20]\end{array}$ & 0.20 & & \\
\hline \multicolumn{13}{|l|}{ Nodal irradiation } \\
\hline \multicolumn{13}{|l|}{ Radiotherapy technique } \\
\hline 3D & $\begin{array}{c}1 \\
191[08 \cdot 412]\end{array}$ & 0.10 & & & $\begin{array}{c}1 \\
118[0.219]\end{array}$ & 061 & & & $\begin{array}{c}1 \\
064[037 \cdot 112]\end{array}$ & 012 & & \\
\hline \multicolumn{13}{|l|}{ Group } \\
\hline Unilateral disease \& unilateral irradiation & 1 & & & & 1 & & & & 1 & & & \\
\hline Unilateral disease \& bilateral irradiation & $0.61[0.23 ; 1.63]$ & 0.32 & & & $0.56[0.25 ; 1.27]$ & 0.166 & & & $1.04[0.45 ; 2.41]$ & 0.92 & & \\
\hline Bilateral disease \& bilateral irradiation & $0.58[0.19 ; 1.80]$ & 0.35 & & & $1.16[0.50 ; 2.67]$ & 0.74 & & & $2.28[0.95 ; 5.44]$ & $0.06^{*}$ & & \\
\hline \multicolumn{13}{|l|}{ Total dose (Gy) } \\
\hline$\leq 56$ & 1 & & & & 1 & & & & 1 & & & \\
\hline$>56$ and $\leq 63$ & $1.96[0.33 ; 11.82]$ & 0.46 & & & $0.68[0.12 ; 3.86]$ & 0.66 & & & $2.30[0.74 ; 7.17]$ & 0.15 & & \\
\hline$>63$ & $1.73[0.40 ; 7.58]$ & 0.46 & & & $1.49[0.52 ; 4.30]$ & 0.46 & & & $1.74[0.68 ; 4.48]$ & 0.25 & & \\
\hline Nodal high-risk level irradiation & $1.52[0.46 ; 5.05]$ & 0.49 & & & $2.57[0.77 ; 8.57]$ & 0.13 & & & $4.23[1.29 ; 13.84]$ & $0.02 *$ & & \\
\hline Nodal medium-risk level irradiation & $1.31[0.59 ; 2.91]$ & 0.51 & & & $0.67[0.34 ; 1.32]$ & 0.25 & & & $1.58[0.92 ; 2.71]$ & $0.10^{*}$ & & \\
\hline Nodal low-risk level irradiation & $0.82[0.24 ; 2.84]$ & 0.76 & & & $1.47[0.45 ; 4.80]$ & 0.52 & & & $0.97[0.42 ; 2.28]$ & 0.95 & & \\
\hline RT interruption $\geq 4$ days & $2.45[0.81 ; 7.42]$ & 0.11 & & & $3.48[1.47 ; 8.21]$ & $0.0045^{*}$ & $3.39[1.46 ; 7.88]$ & $<0.01$ & $3.23[1.57 ; 6.63]$ & $<0.01 *$ & $3.81[1.71 ; 8.50]$ & $<0.01$ \\
\hline \multicolumn{13}{|l|}{ Mucosal irradiation } \\
\hline Mucosal irradiation & $0.30[0.13 ; 0.69]$ & $\angle 0.01^{*}$ & $0.30[0.13 ; 0.69]$ & $<0.01$ & $0.70[0.31 ; 1.57]$ & 0.39 & & & $0.64[0.33 ; 1.26]$ & 0.20 & & \\
\hline Total dose $>50 \mathrm{~Gy}$ & $2.10[0.84 ; 5.28]$ & 0.11 & & & & & & & & & & \\
\hline Nasopharynx & $0.56[0.21 ; 1.50]$ & 0.25 & & & & & & & & & & \\
\hline Oropharynx & $0.33[0.04 ; 2.74]$ & 0.31 & & & & & & & & & & \\
\hline Hypopharynx & $1.09[0.25 ; 4.74]$ & 0.91 & & & & & & & & & & \\
\hline Larynx & $2.19[0.51 ; 9.48]$ & 0.30 & & & & & & & & & & \\
\hline Oral cavity & $2.31[0.90 ; 5.96]$ & 0.08 & & & & & & & & & & \\
\hline \multicolumn{13}{|l|}{ Chemotherapy } \\
\hline Neoadjuvant & $1.14[0.34 ; 3.86]$ & 0.83 & & & $2.78[1.33 ; 5.80]$ & $<0.01^{*}$ & & & $2.53[1.27 ; 5.06]$ & $<0.01 *$ & $2.52[1.19 ; 5.33]$ & 0.02 \\
\hline Concomitant & $0.48[0.22 ; 1.03]$ & $0.06^{*}$ & & & $0.98[0.52 ; 1.83]$ & 0.94 & & & $0.85[0.52 ; 1.39]$ & 0.51 & & \\
\hline
\end{tabular}

*Variables included in multivariate analysis with backward selection

HR 95\% CI, Hazard ratio 95\% confidence interval; 18 FDG PET, 18Fluorodeoxyglucose positron emission tomography; SCC, Squamous cell carcinoma; IMRT, Intensity-modulated radiation therapy; 3D, Three-

bilateral irradiation; Gy, Gray; NRT, Nodal radiotherapy; HR, High risk level; IR, Intermediate risk level; LR, Low risk level; RT, radiotherapy 
Table 5: Acute and late adverse events grade 3-4 for the 297 patients with an available evaluation according to the side of irradiation and technique.

\begin{tabular}{|c|c|c|c|c|c|c|c|c|c|c|}
\hline & \multirow{2}{*}{ Global } & \multirow{2}{*}{$\begin{array}{c}\text { Unilateral } \\
\text { NRT }\end{array}$} & \multirow{2}{*}{$\begin{array}{l}\text { Bilateral } \\
\text { NRT }\end{array}$} & \multirow{2}{*}{$\mathrm{p}$} & \multicolumn{3}{|c|}{ Unilateral NRT } & \multicolumn{3}{|c|}{ Bilateral NRT } \\
\hline & & & & & $2 D$ or $3 D$ & IMRT & $\mathrm{p}$ & $2 D$ or $3 D$ & IMRT & $\mathrm{p}$ \\
\hline $\begin{array}{l}\text { Number of available data } \\
\text { Acute toxicities }\end{array}$ & 297 & 64 & 242 & & 10 & 54 & & 127 & 115 & \\
\hline Dysphagia & $78(26.2 \%)$ & $8(12.7 \%)$ & $70(29.8 \%)$ & $<0.01$ & $0 \%(0)$ & $15.1 \%(8)$ & 0.33 & $33.1 \%(41)$ & $26.1 \%(29)$ & 0.25 \\
\hline Mucositis & $69(23.3 \%)$ & $10(16.4 \%)$ & $59(25.1 \%)$ & 0.15 & $11.1 \%(1)$ & $17.3 \%(9)$ & 1 & $29.0 \%$ & $20.7 \%(23)$ & 0.14 \\
\hline Pain & $45(15.0 \%)$ & $4(6.3 \%)$ & $41(17.3 \%)$ & 0.03 & $0 \%(0)$ & $7.4 \%(4)$ & $\mathrm{Nc}$ & $15.9 \%(20)$ & $18.9 \%(21)$ & 0.54 \\
\hline Dermatitis & $0(0 \%)$ & $0(0 \%)$ & $0(0 \%)$ & $\mathrm{Nc}$ & 0 & 0 & & 0 & 0 & \\
\hline Other acute toxicity & $11(3.6 \%)$ & $2(3.2 \%)$ & $9(3.8 \%)$ & 1 & $10 \%(1)$ & $1.96 \%(1)$ & & $6(4.8 \%)$ & $3(2.7 \%)$ & 0.51 \\
\hline \multicolumn{11}{|l|}{ Late toxicities } \\
\hline Xerostomia & $40(13.5 \%)$ & $1(1.6 \%)$ & $39(16.5 \%)$ & $<0.01$ & $10 \%(1)$ & $0 \%(0)$ & $\mathrm{Nc}$ & $25.8 \%(32)$ & $6.3 \%(7)$ & $<0.01$ \\
\hline Dysphagia & $22(7.4 \%)$ & $0(0 \%)$ & $22(9.3 \%)$ & $<0.01$ & 0 & 0 & & $15.3 \%(19)$ & $2.7 \%(3)$ & $<0.01$ \\
\hline Fibrosis & $18(6.1 \%)$ & $2(3.3 \%)$ & $16(6.8 \%)$ & 0.54 & $10 \%(1)$ & $1.96 \%(1)$ & $\mathrm{Nc}$ & $12.1 \%(15)$ & $0.9 \%(1)$ & $<0.01$ \\
\hline Pain & $8(2.7 \%)$ & $1(1.6 \%)$ & $7(3.0 \%)$ & 1 & $0 \%(0)$ & $1.96 \%(1)$ & $\mathrm{Nc}$ & $4.84 \%(6)$ & $0.9 \%(1)$ & 0.13 \\
\hline Osteonecrosis & $4(1.3 \%)$ & $0(0 \%)$ & $4(1.7 \%)$ & $\mathrm{Nc}$ & 0 & 0 & & $3.23 \%(4)$ & $0 \%(0)$ & 0.12 \\
\hline Second cancer & $4(1.3 \%)$ & $0(0 \%)$ & $4(1.7 \%)$ & $\mathrm{Nc}$ & 0 & 0 & & $3.2 \%(4)$ & 0 & 0.12 \\
\hline Oesophageal stricture & $3(1.0 \%)$ & $0(0 \%)$ & $3(1.3 \%)$ & $\mathrm{Nc}$ & 0 & 0 & & $2.42 \%(3)$ & $0 \%(0)$ & 0.26 \\
\hline Trismus & $1(0.3 \%)$ & $0(0 \%)$ & $1(0.4 \%)$ & $\mathrm{Nc}$ & 0 & 0 & & $0.81 \%(1)$ & $0 \%(0)$ & $\mathrm{Nc}$ \\
\hline Other & $8(2.7 \%)$ & $1(1.6 \%)$ & $7(3.0 \%)$ & 1 & $1(10.0 \%)$ & 0 & $\mathrm{Nc}$ & $4.0 \%(5)$ & $1.8 \%(2)$ & 0.45 \\
\hline
\end{tabular}


Side of regional relapse for bilateral disease according to radiotherapy target volume

\begin{tabular}{c|ccc}
\hline \multirow{2}{*}{$\begin{array}{c}\text { Side of relapse for } \\
\text { bilateral disease }\end{array}$} & \multicolumn{3}{|c}{ Radiotherapy target volume } \\
\cline { 2 - 4 } & High-risk nodal level & $\begin{array}{c}\text { Intermediate risk nodal } \\
\text { level }\end{array}$ & Low risk nodal level \\
\hline Bilateral & $\mathrm{X}$ & $\mathrm{X}$ & $\mathrm{X}$ \\
\hline Bilateral & $\mathrm{X}$ & $\mathrm{X}$ & $\mathrm{X}$ \\
\hline Bilateral & & $\mathrm{X}$ & $\mathrm{X}$ \\
\hline Bilateral & $\mathrm{X}$ & & $\mathrm{X}$ \\
\hline Unilateral & $\mathrm{X}$ & & \\
\hline
\end{tabular}

Side of regional relapse for unilateral disease according to radiotherapy target volume for ipsilateral and contralateral sides

\begin{tabular}{|c|c|c|c|c|c|c|}
\hline \multirow{3}{*}{$\begin{array}{l}\text { Side of } \\
\text { relapse for } \\
\text { unilateral } \\
\text { disease }\end{array}$} & \multicolumn{6}{|c|}{ Radiotherapy target volume } \\
\hline & \multicolumn{3}{|c|}{ Ipsilateral } & \multicolumn{3}{|c|}{ Contralateral } \\
\hline & $\begin{array}{l}\text { High-risk } \\
\text { nodal level }\end{array}$ & $\begin{array}{l}\text { Intermediate } \\
\text { risk nodal } \\
\text { level }\end{array}$ & $\begin{array}{l}\text { Low risk } \\
\text { nodal } \\
\text { level }\end{array}$ & $\begin{array}{l}\text { High-risk } \\
\text { nodal level }\end{array}$ & $\begin{array}{l}\text { Intermediate } \\
\text { risk nodal } \\
\text { level }\end{array}$ & $\begin{array}{l}\text { Low } \\
\text { risk } \\
\text { nodal } \\
\text { level }\end{array}$ \\
\hline Bilateral & $X$ & $\mathrm{X}$ & & & & \\
\hline Bilateral & $X$ & $\mathrm{X}$ & $\mathrm{X}$ & & & $X$ \\
\hline Bilateral & $\mathrm{X}$ & & $\mathrm{X}$ & & & $\mathrm{X}$ \\
\hline Bilateral & $\mathrm{X}$ & $\mathrm{X}$ & & $X$ & $X$ & \\
\hline Bilateral & $\mathrm{X}$ & $\mathrm{X}$ & $\mathrm{X}$ & & & $X$ \\
\hline Bilateral & $\mathrm{X}$ & & $\mathrm{X}$ & & & \\
\hline Contralateral & $X$ & & $X$ & & & $X$ \\
\hline Contralateral & $\mathrm{X}$ & & & & & \\
\hline Contralateral & $\mathrm{X}$ & & $\mathrm{X}$ & $\mathrm{X}$ & & $\mathrm{X}$ \\
\hline Contralateral & $\mathrm{X}$ & & $\mathrm{X}$ & & & \\
\hline Contralateral & missing & missing & missing & missing & missing & missing \\
\hline Contralateral & $\mathrm{X}$ & & $X$ & & & $X$ \\
\hline Contralateral & $\mathrm{X}$ & & $\mathrm{X}$ & & & \\
\hline Ipsilateral & $X$ & & $\mathrm{X}$ & & & $X$ \\
\hline Ipsilateral & $X$ & & $\mathrm{X}$ & & & $X$ \\
\hline Ipsilateral & $\mathrm{X}$ & $X$ & & & & $X$ \\
\hline Ipsilateral & $\mathrm{X}$ & & $\mathrm{X}$ & & & $X$ \\
\hline Ipsilateral & $\mathrm{X}$ & $X$ & $X$ & & $X$ & $X$ \\
\hline Ipsilateral & & $X$ & & & & $X$ \\
\hline Ipsilateral & $X$ & $X$ & & & & $\mathrm{X}$ \\
\hline Ipsilateral & $X$ & & $\mathrm{X}$ & & & \\
\hline Ipsilateral & $\mathrm{X}$ & & & & & $X$ \\
\hline Ipsilateral & $\mathrm{X}$ & & $\mathrm{X}$ & & & $X$ \\
\hline Ipsilateral & $\mathrm{X}$ & & & & & $X$ \\
\hline Ipsilateral & $\mathrm{X}$ & & $\mathrm{X}$ & & & \\
\hline Ipsilateral & $X$ & $X$ & & & & $X$ \\
\hline Ipsilateral & $\mathrm{X}$ & $X$ & $X$ & & & $X$ \\
\hline Ipsilateral & $\mathrm{X}$ & & $\mathrm{X}$ & & & $\mathrm{X}$ \\
\hline Ipsilateral & missing & missing & missing & missing & missing & missing \\
\hline Ipsilateral & $\mathrm{X}$ & & & & & $X$ \\
\hline Ipsilateral & $\mathrm{X}$ & & $X$ & & & \\
\hline Ipsilateral & missing & missing & missing & missing & missing & missing \\
\hline Ipsilateral & missing & missing & missing & missing & missing & missing \\
\hline Ipsilateral & $\mathrm{X}$ & $\mathrm{X}$ & $\mathrm{X}$ & & $X$ & $X$ \\
\hline Ipsilateral & $X$ & & $X$ & & & $X$ \\
\hline Ipsilateral & $\mathrm{X}$ & $\mathrm{X}$ & $\mathrm{X}$ & & & \\
\hline
\end{tabular}


Details of mucosal local relapse

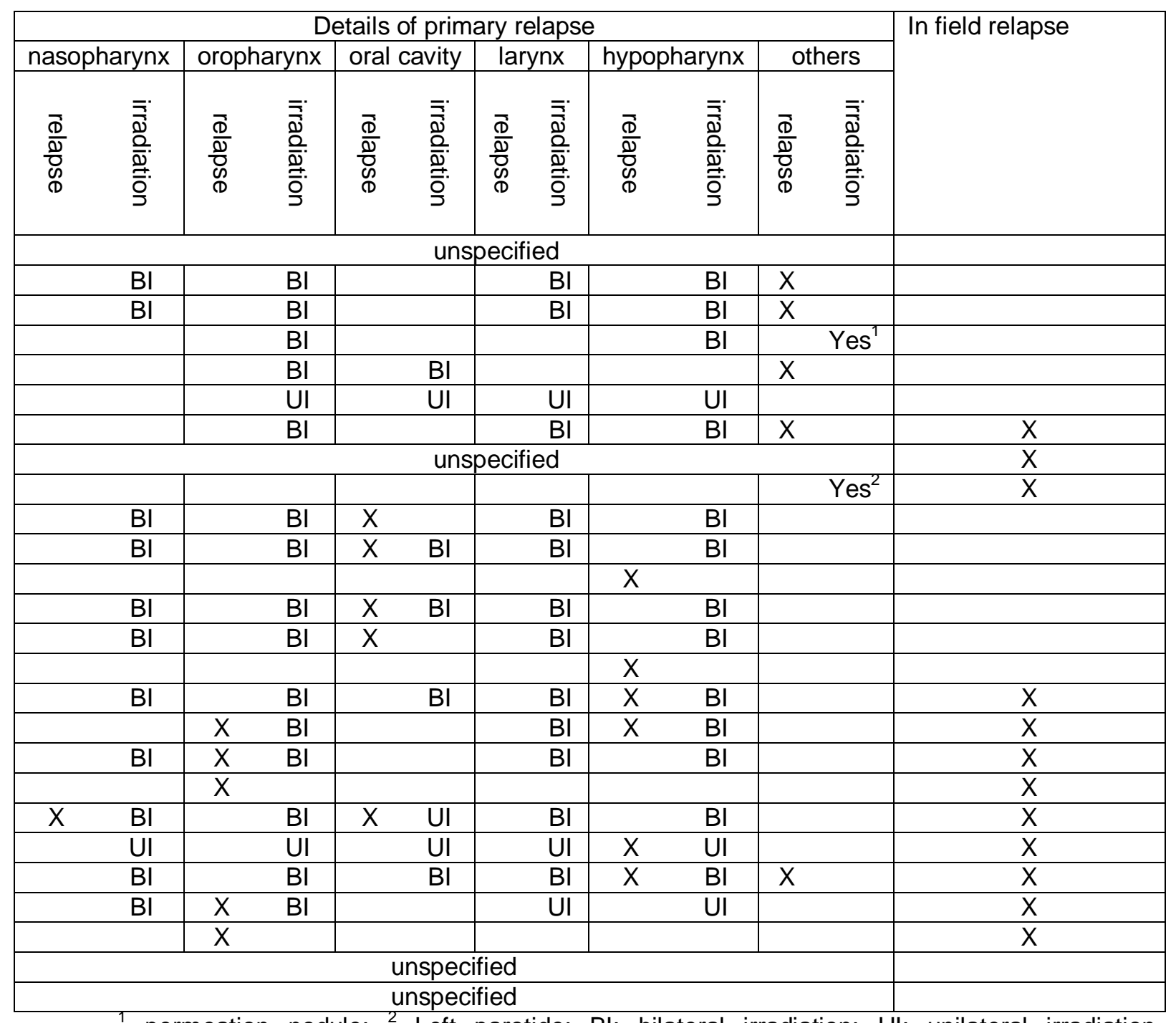

permeation nodule; ${ }^{2}$ Left parotide; BI: bilateral irradiation; UI: unilateral irradiation 


\section{Local relapses}

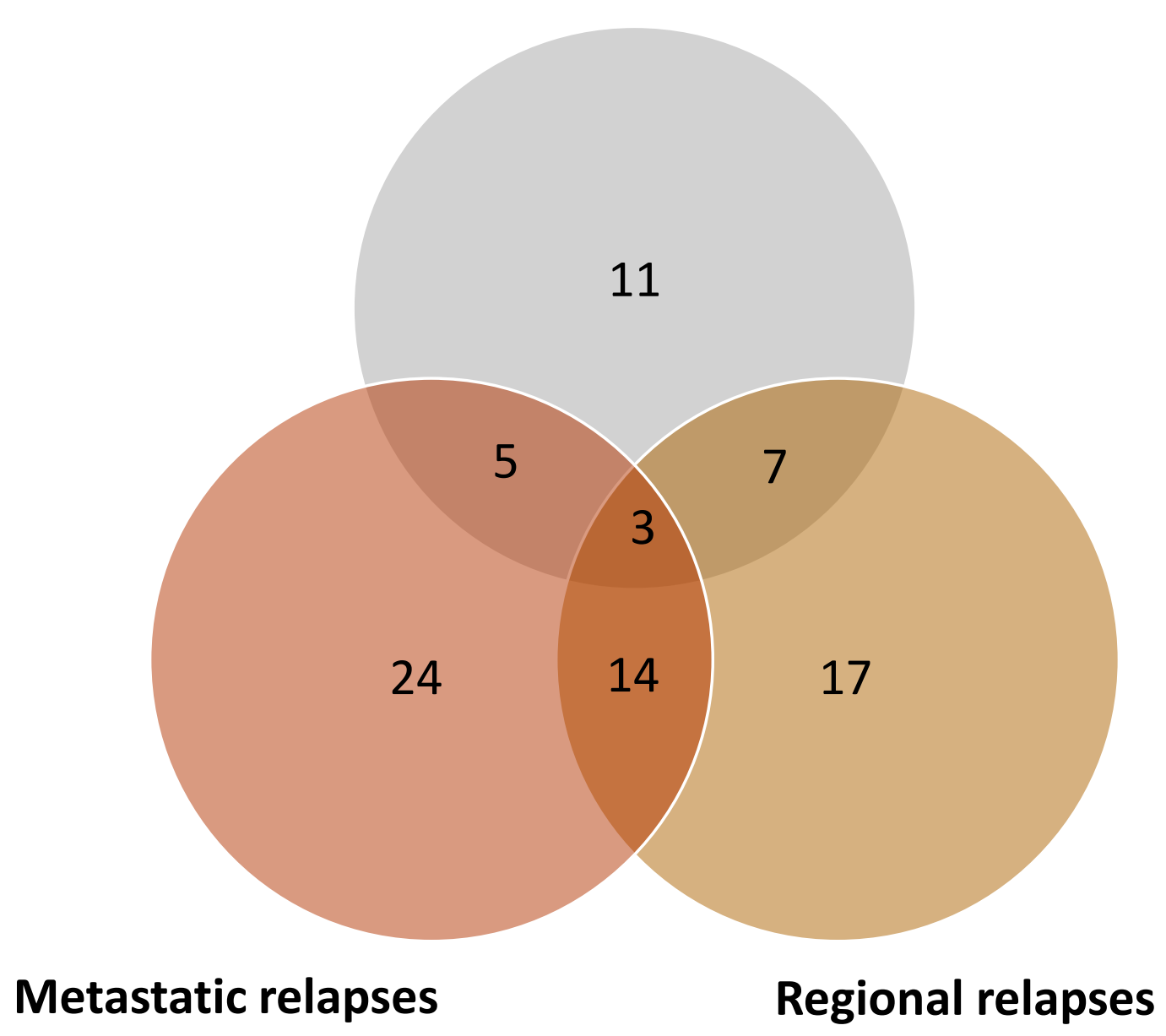


a - Cumulative incidence of local relapse

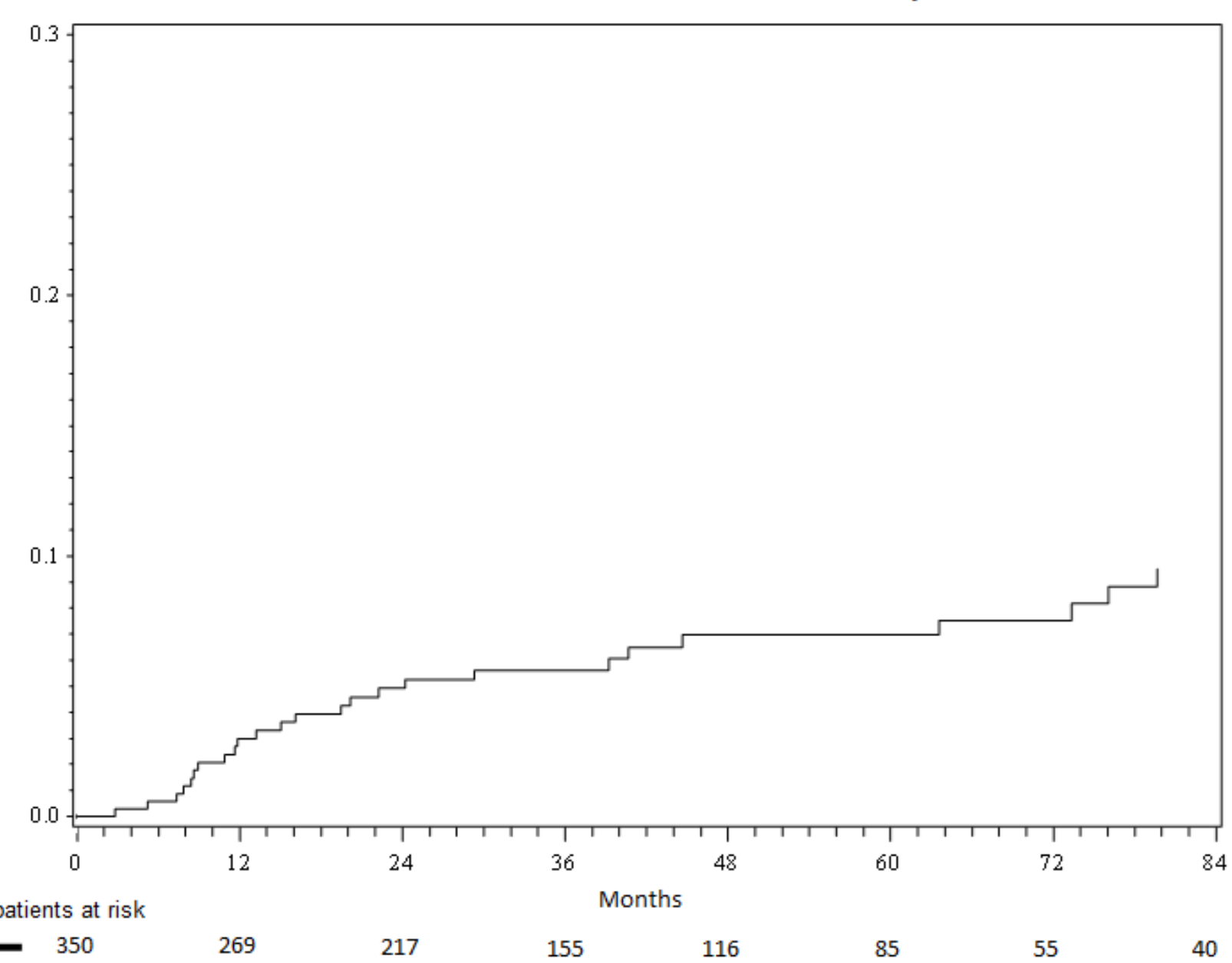

b -Cumulative incidence of regional relapse

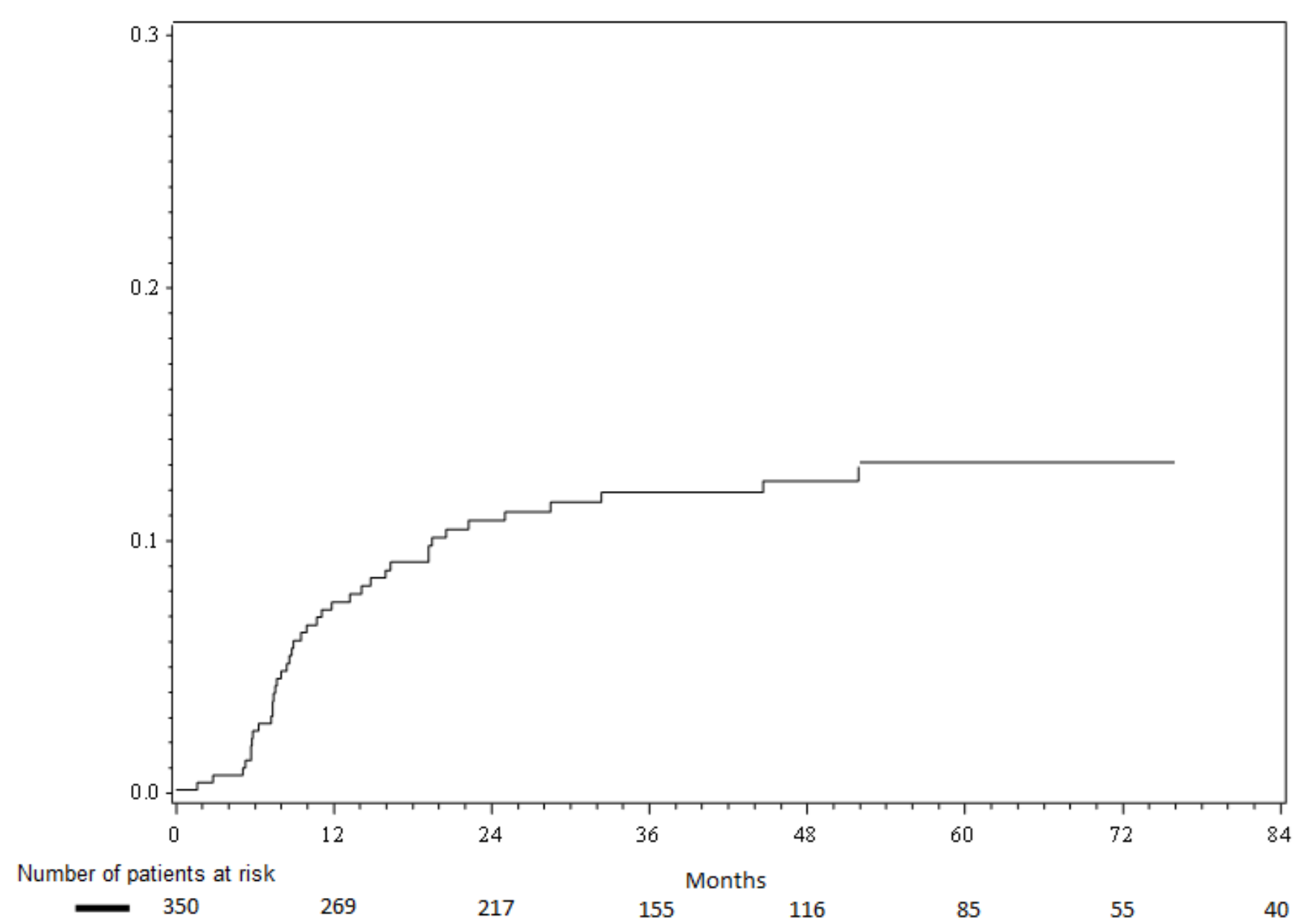

c - Cumulative incidence of CUP specific survival

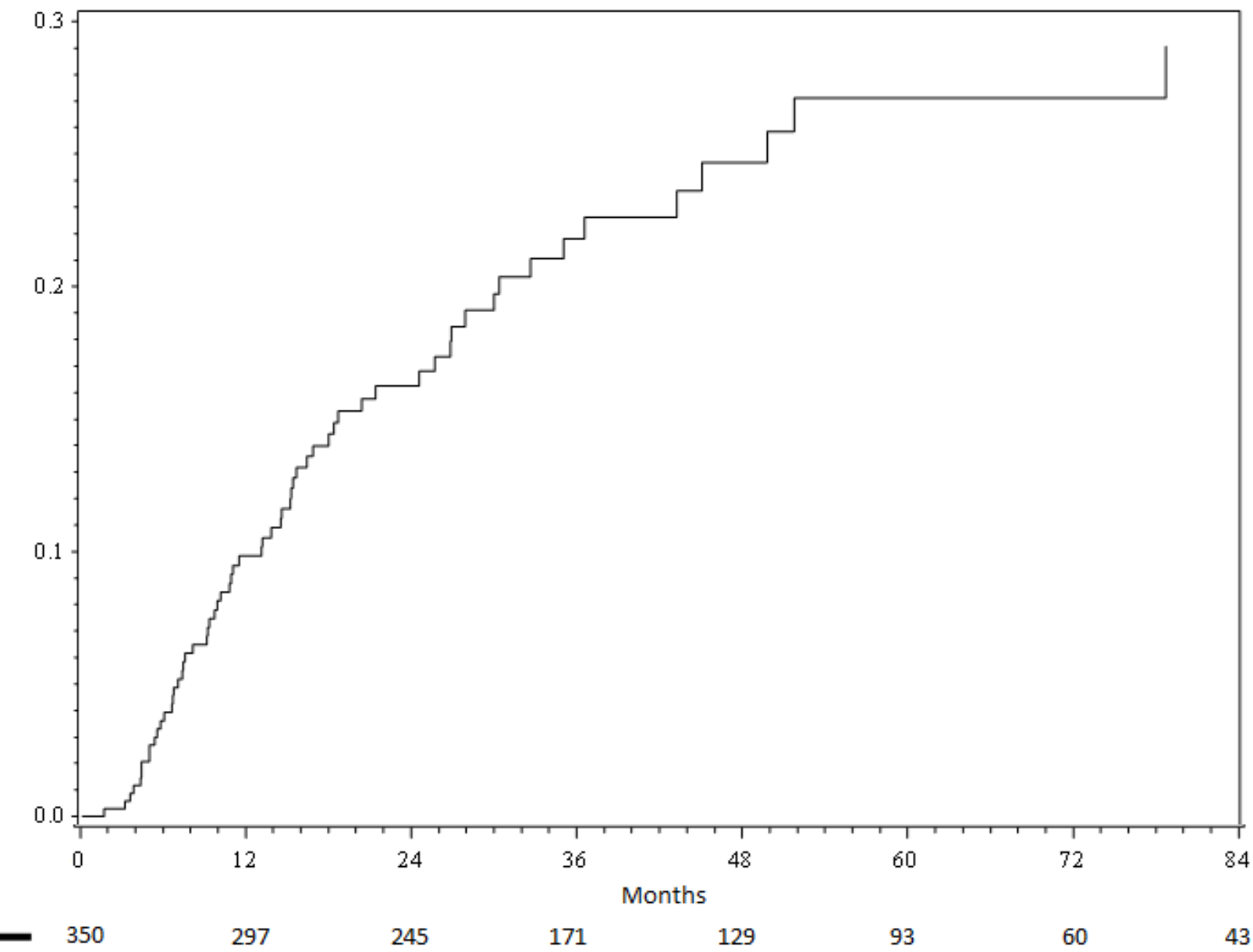


a- Cumulative incidence of local relapse

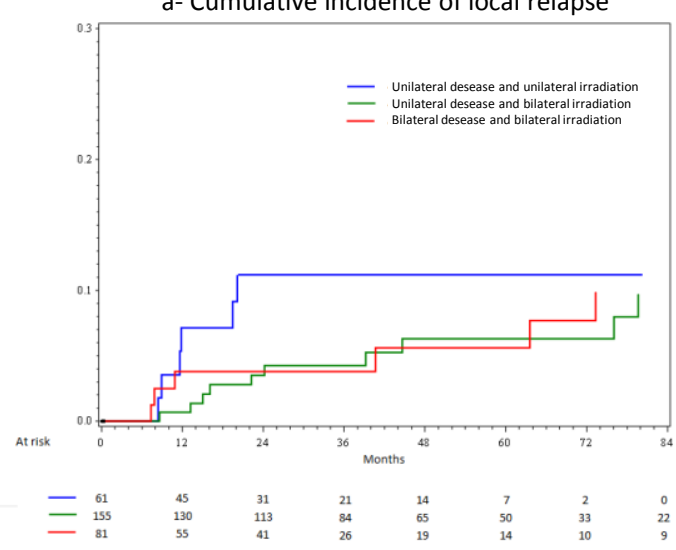

b - Cumulative incidence of regional relapse

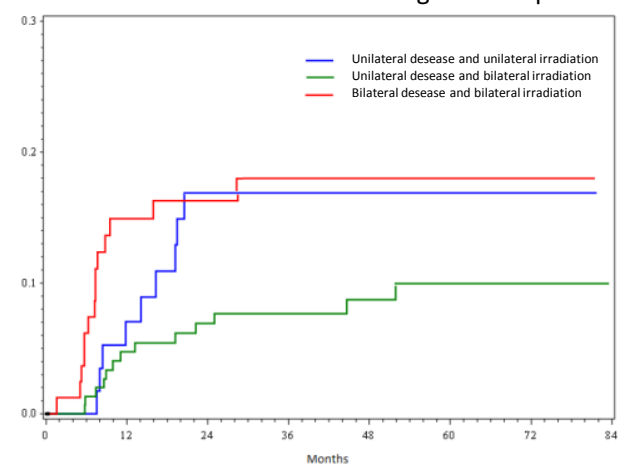

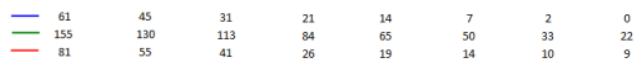

c - Cumulative incidence of locoregional relapse

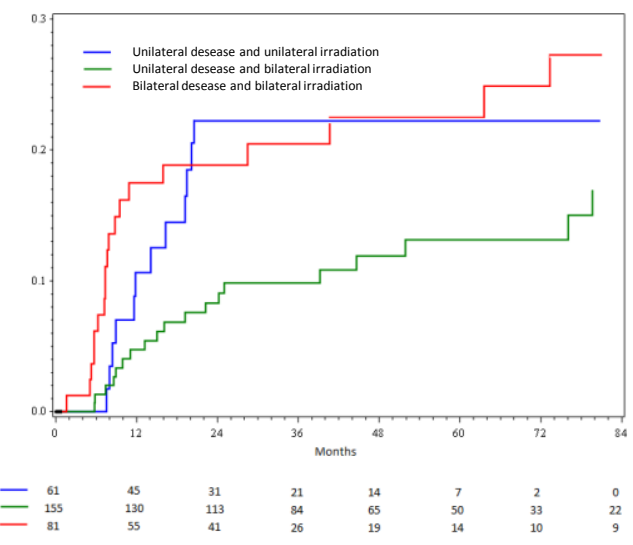

d - Cumulative incidence of CUP specific survival

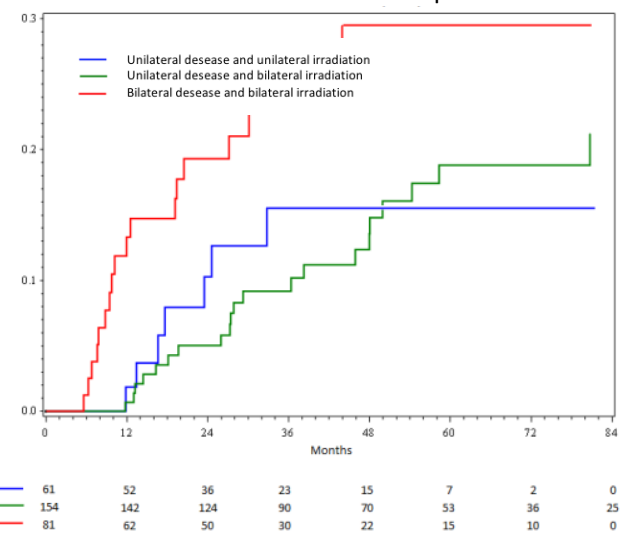




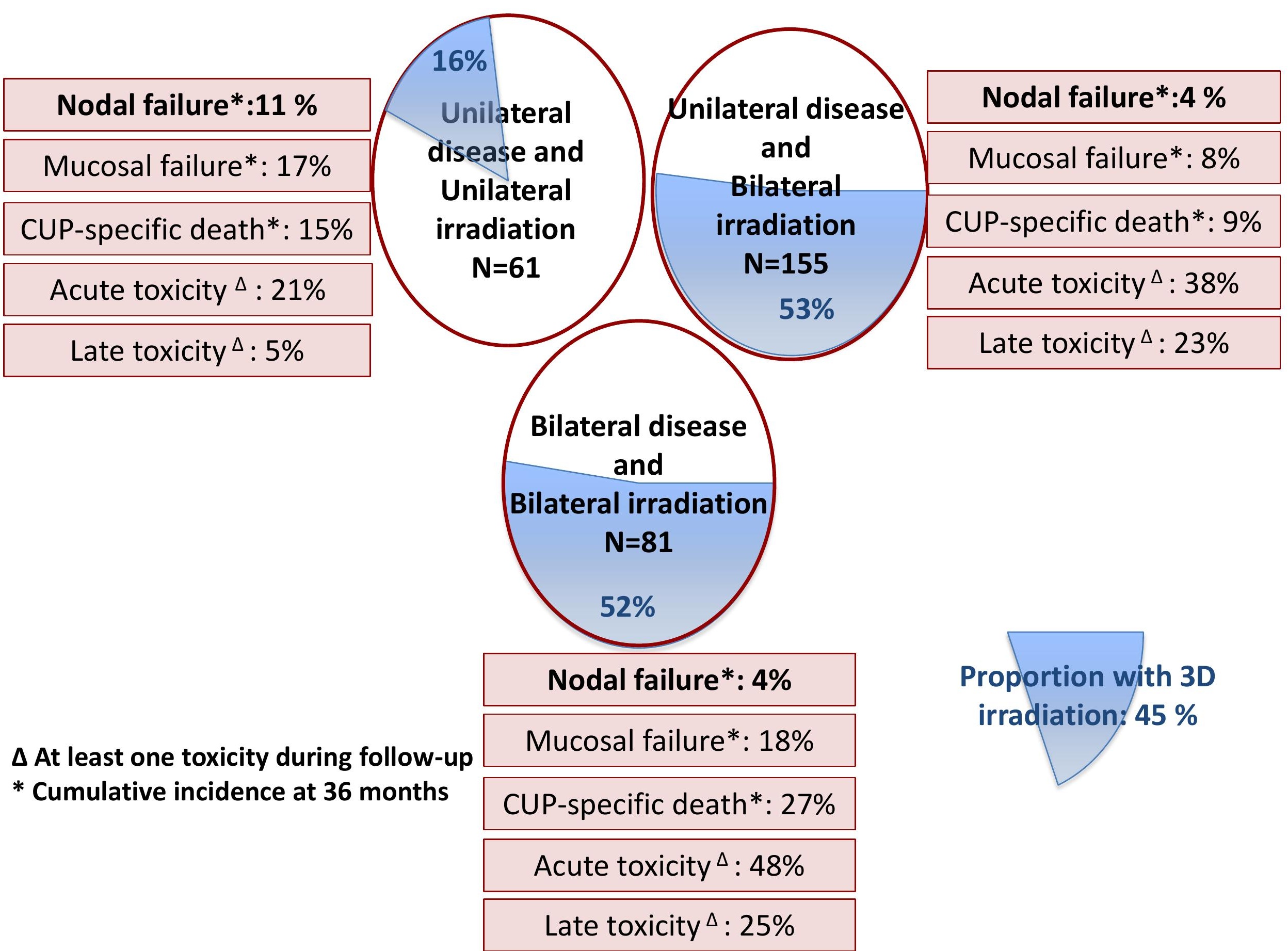


Table 6: sides of regional and mucosal relapses

Side of regional relapse for bilateral disease according to radiotherapy target volume

\begin{tabular}{c|ccc}
\hline \multirow{2}{*}{$\begin{array}{c}\text { Side of relapse for } \\
\text { bilateral disease }\end{array}$} & \multicolumn{3}{|c}{ Radiotherapy target volume } \\
\cline { 2 - 4 } & High-risk nodal level & $\begin{array}{c}\text { Intermediate risk nodal } \\
\text { level }\end{array}$ & Low risk nodal level \\
\hline Bilateral & $\mathrm{X}$ & $\mathrm{X}$ & $\mathrm{X}$ \\
\hline Bilateral & $\mathrm{X}$ & $\mathrm{X}$ \\
\hline Bilateral & & $\mathrm{X}$ & $\mathrm{X}$ \\
\hline Bilateral & $\mathrm{X}$ & $\mathrm{X}$ \\
\hline Unilateral & $\mathrm{X}$ & \\
\hline
\end{tabular}

Side of regional relapse for unilateral disease according to radiotherapy target volume for ipsilateral and contralateral sides

\begin{tabular}{|c|c|c|c|c|c|c|}
\hline \multirow{3}{*}{$\begin{array}{l}\text { Side of } \\
\text { relapse for } \\
\text { unilateral } \\
\text { disease }\end{array}$} & \multicolumn{6}{|c|}{ Radiotherapy target volume } \\
\hline & \multicolumn{3}{|c|}{ Ipsilateral } & \multicolumn{3}{|c|}{ Contralateral } \\
\hline & $\begin{array}{l}\text { High-risk } \\
\text { nodal level }\end{array}$ & $\begin{array}{l}\text { Intermediate } \\
\text { risk nodal } \\
\text { level }\end{array}$ & $\begin{array}{c}\text { Low risk } \\
\text { nodal } \\
\text { level }\end{array}$ & $\begin{array}{l}\text { High-risk } \\
\text { nodal level }\end{array}$ & $\begin{array}{c}\text { Intermediate } \\
\text { risk nodal } \\
\text { level }\end{array}$ & $\begin{array}{l}\text { Low } \\
\text { risk } \\
\text { nodal } \\
\text { level }\end{array}$ \\
\hline Bilateral & $\mathrm{X}$ & $\mathrm{X}$ & & & & \\
\hline Bilateral & $\mathrm{X}$ & $\mathrm{X}$ & $\mathrm{X}$ & & & $\mathrm{X}$ \\
\hline Bilateral & $\mathrm{X}$ & & $\mathrm{X}$ & & & $\mathrm{X}$ \\
\hline Bilateral & $\mathrm{X}$ & $\mathrm{X}$ & & $\mathrm{X}$ & $\mathrm{X}$ & \\
\hline Bilateral & $\mathrm{X}$ & $\mathrm{X}$ & $\mathrm{X}$ & & & $\mathrm{X}$ \\
\hline Bilateral & $\mathrm{X}$ & & $\mathrm{X}$ & & & \\
\hline Contralateral & $\mathrm{X}$ & & $\mathrm{X}$ & & & $\mathrm{X}$ \\
\hline Contralateral & $\mathrm{X}$ & & & & & \\
\hline Contralateral & $\mathrm{X}$ & & $\mathrm{X}$ & $\mathrm{X}$ & & $X$ \\
\hline Contralateral & $\mathrm{X}$ & & $\mathrm{X}$ & & & \\
\hline Contralateral & missing & missing & missing & missing & missing & missing \\
\hline Contralateral & $\mathrm{X}$ & & $\mathrm{X}$ & & & $\mathrm{X}$ \\
\hline Contralateral & $\mathrm{X}$ & & $\mathrm{X}$ & & & \\
\hline Ipsilateral & $\mathrm{X}$ & & $\mathrm{X}$ & & & $\mathrm{X}$ \\
\hline Ipsilateral & $\mathrm{X}$ & & $\bar{X}$ & & & $\mathrm{X}$ \\
\hline Ipsilateral & $X$ & $\mathrm{X}$ & & & & $X$ \\
\hline Ipsilateral & $\mathrm{X}$ & & $\mathrm{X}$ & & & $\mathrm{X}$ \\
\hline |psilateral & $\mathrm{X}$ & $X$ & $\bar{X}$ & & $\mathrm{X}$ & $\mathrm{X}$ \\
\hline Ipsilateral & & $\mathrm{X}$ & & & & $X$ \\
\hline Ipsilateral & $\mathrm{X}$ & $\bar{X}$ & & & & $\mathrm{X}$ \\
\hline Ipsilateral & $X$ & & $\mathrm{X}$ & & & \\
\hline Ipsilateral & $\mathrm{X}$ & & & & & $X$ \\
\hline Ipsilateral & $\mathrm{X}$ & & $\mathrm{X}$ & & & $X$ \\
\hline Ipsilateral & $\mathrm{X}$ & & & & & $X$ \\
\hline Ipsilateral & $\mathrm{X}$ & & $X$ & & & \\
\hline Ipsilateral & $\mathrm{X}$ & $\mathrm{X}$ & & & & $X$ \\
\hline Ipsilateral & $\mathrm{X}$ & $\mathrm{X}$ & $\mathrm{X}$ & & & $X$ \\
\hline Ipsilateral & $\mathrm{X}$ & & $\mathrm{X}$ & & & $\mathrm{X}$ \\
\hline Ipsilateral & missing & missing & missing & missing & missing & missing \\
\hline Ipsilateral & $\mathrm{X}$ & & & & & $\mathrm{X}$ \\
\hline Ipsilateral & $\mathrm{X}$ & & $\mathrm{X}$ & & & \\
\hline Ipsilateral & missing & missing & missing & missing & missing & missing \\
\hline Ipsilateral & missing & missing & missing & missing & missing & missing \\
\hline Ipsilateral & $X$ & $\mathrm{X}$ & $\mathrm{X}$ & & $\mathrm{X}$ & $X$ \\
\hline Ipsilateral & $\mathrm{X}$ & & $\mathrm{X}$ & & & $\mathrm{X}$ \\
\hline Ipsilateral & $\mathrm{X}$ & $\mathrm{X}$ & $\mathrm{X}$ & & & \\
\hline
\end{tabular}


Details of mucosal local relapse

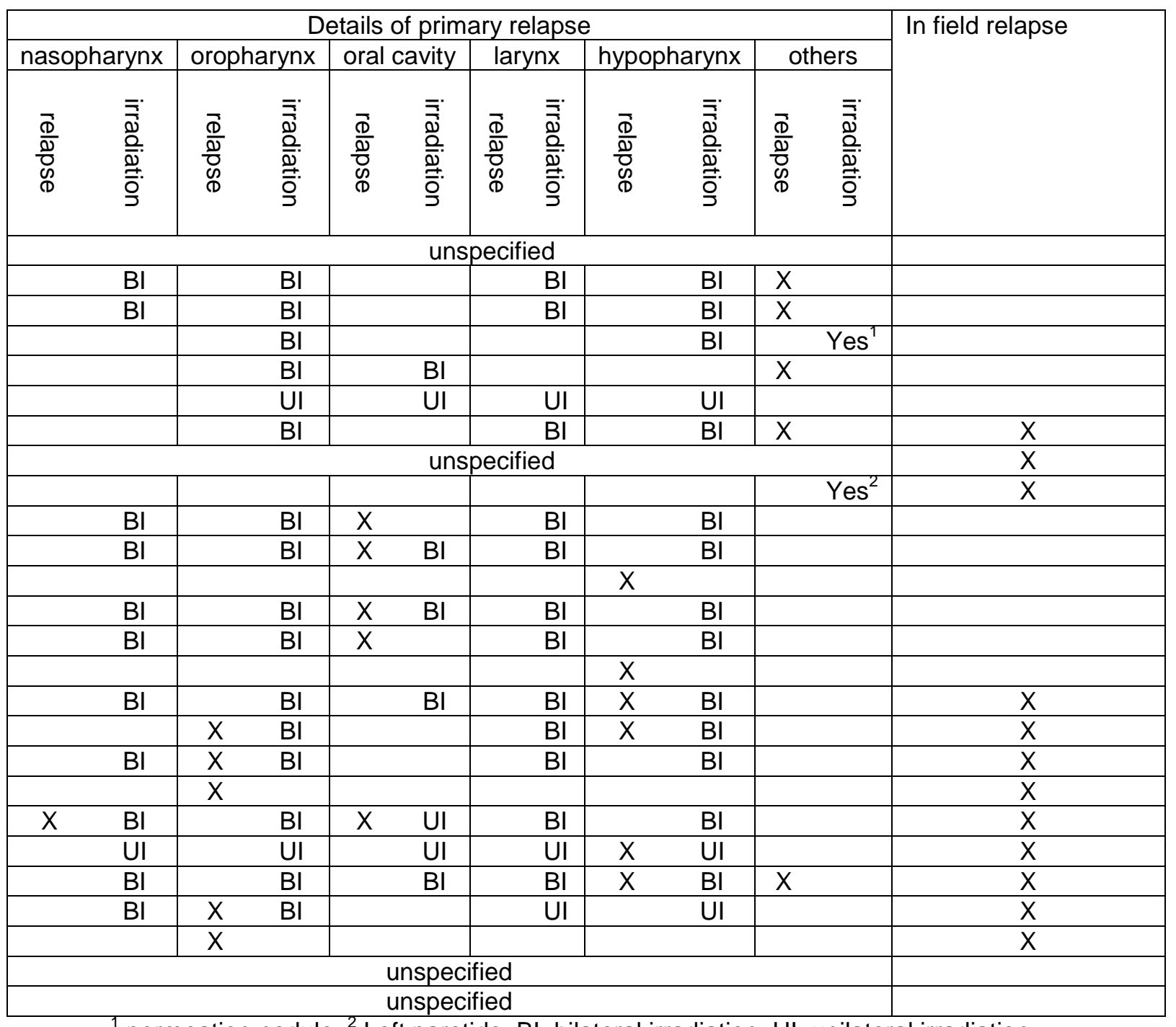

permeation nodule; ${ }^{2}$ Left parotide; BI: bilateral irradiation; UI: unilateral irradiation 